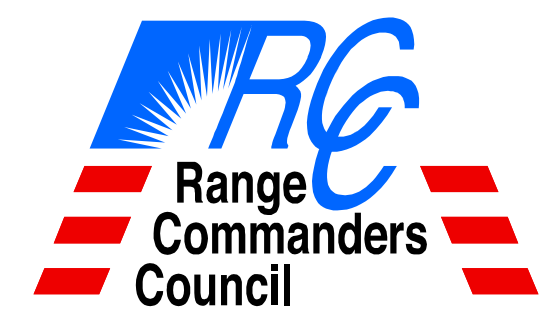

METEOROLOGY GROUP

\title{
RANGE ATMOSPHERIC AND OCEANIC ENVIRONMENTAL SUPPORT CAPABILITIES
}

\author{
WHITE SANDS MISSILE RANGE \\ REAGAN TEST SITE \\ YUMA PROVING GROUND \\ DUGWAY PROVING GROUND \\ ABERDEEN TEST CENTER \\ ELECTRONIC PROVING GROUND
}

NAVAL AIR WARFARE CENTER WEAPONS DIVISION, POINT MUGU NAVAL AIR WARFARE CENTER WEAPONS DIVISION, CHINA LAKE NAVAL AIR WARFARE CENTER AIRCRAFT DIVISION, PATUXENT RIVER NAVAL UNDERSEA WARFARE CENTER DIVISION, NEWPORT

PACIFIC MISSILE RANGE FACILITY

NAVAL UNDERSEA WARFARE CENTER DIVISION, KEYPORT

30TH SPACE WING 45TH SPACE WING

AIR FORCE FLIGHT TEST CENTER AIR ARMAMENT CENTER ARNOLD ENGINEERING DEVELOPMENT CENTER

NATIONAL AERONAUTICS AND SPACE ADMINISTRATION (NASA)

DISTRIBUTION A: APPROVED FOR PUBLIC RELEASE;

DISTRIBUTION IS UNLIMITED 


\section{Report Documentation Page}

Form Approved

OMB No. 0704-0188

Public reporting burden for the collection of information is estimated to average 1 hour per response, including the time for reviewing instructions, searching existing data sources, gathering and maintaining the data needed, and completing and reviewing the collection of information. Send comments regarding this burden estimate or any other aspect of this collection of information,

including suggestions for reducing this burden, to Washington Headquarters Services, Directorate for Information Operations and Reports, 1215 Jefferson Davis Highway, Suite 1204, Arlington

VA 22202-4302. Respondents should be aware that notwithstanding any other provision of law, no person shall be subject to a penalty for failing to comply with a collection of information if it

does not display a currently valid OMB control number.

\begin{tabular}{|c|c|c|}
\hline $\begin{array}{l}\text { 1. REPORT DATE } \\
\text { DEC } 2011\end{array}$ & 2. REPORT TYPE & $\begin{array}{l}\text { 3. DATES COVERED } \\
\mathbf{0 0 - 0 1 - 2 0 0 7} \text { to 00-07-2011 }\end{array}$ \\
\hline \multirow{3}{*}{\multicolumn{2}{|c|}{$\begin{array}{l}\text { 4. TITLE AND SUBTITLE } \\
\text { Range Atmospheric and Oceanic Environmental Support Capabilities }\end{array}$}} & 5a. CONTRACT NUMBER \\
\hline & & 5b. GRANT NUMBER \\
\hline & & 5c. PROGRAM ELEMENT NUMBER \\
\hline \multirow{3}{*}{\multicolumn{2}{|c|}{ 6. $\operatorname{AUTHOR}(\mathrm{S})$}} & 5d. PROJECT NUMBER \\
\hline & & $\begin{array}{l}\text { 5e. TASK NUMBER } \\
\text { MG-020 }\end{array}$ \\
\hline & & 5f. WORK UNIT NUMBER \\
\hline \multicolumn{2}{|c|}{$\begin{array}{l}\text { 7. PERFORMING ORGANIZATION NAME(S) AND ADDRESS(ES) } \\
\text { Range Commanders Council,1510 Headquarters Avenue, White Sands } \\
\text { Missile Range,NM,88002 }\end{array}$} & $\begin{array}{l}\text { 8. PERFORMING ORGANIZATION } \\
\text { REPORT NUMBER } \\
\text { 354-11 }\end{array}$ \\
\hline \multirow{2}{*}{\multicolumn{2}{|c|}{ 9. SPONSORING/MONITORING AGENCY NAME(S) AND ADDRESS(ES) }} & 10. SPONSOR/MONITOR'S ACRONYM(S) \\
\hline & & $\begin{array}{l}\text { 11. SPONSOR/MONITOR'S REPORT } \\
\text { NUMBER(S) }\end{array}$ \\
\hline
\end{tabular}

12. DISTRIBUTION/AVAILABILITY STATEMENT

Approved for public release; distribution unlimited

13. SUPPLEMENTARY NOTES

14. ABSTRACT

Provides identification of individual range capabilities, requirements, procurement, and specialized data sets and databases for natural and oceanic environments.

15. SUBJECT TERMS

Meteorology Group

\begin{tabular}{|c|c|c|c|c|c|}
\hline \multicolumn{3}{|c|}{ 16. SECURITY CLASSIFICATION OF: } & 17. LIMITATION OF & 18. NUMBER & 19a. NAME OF \\
\hline $\begin{array}{c}\text { a. REPORT } \\
\text { unclassified }\end{array}$ & $\begin{array}{c}\text { b. ABSTRACT } \\
\text { unclassified }\end{array}$ & $\begin{array}{c}\text { c. THIS PAGE } \\
\text { unclassified }\end{array}$ & $\begin{array}{c}\text { Same as } \\
\text { Report (SAR) }\end{array}$ & 62 & \\
\hline
\end{tabular}




\section{Report Documentation Page}

Form Approved

OMB No. 0704-0188

Public reporting burden for the collection of information is estimated to average 1 hour per response, including the time for reviewing instructions, searching existing data sources, gathering and maintaining the data needed, and completing and reviewing the collection of information. Send comments regarding this burden estimate or any other aspect of this collection of information,

including suggestions for reducing this burden, to Washington Headquarters Services, Directorate for Information Operations and Reports, 1215 Jefferson Davis Highway, Suite 1204, Arlington

VA 22202-4302. Respondents should be aware that notwithstanding any other provision of law, no person shall be subject to a penalty for failing to comply with a collection of information if it

does not display a currently valid OMB control number.

\begin{tabular}{|c|c|c|}
\hline $\begin{array}{l}\text { 1. REPORT DATE } \\
\text { DEC } 2011\end{array}$ & 2. REPORT TYPE & $\begin{array}{l}\text { 3. DATES COVERED } \\
\mathbf{0 0 - 0 1 - 2 0 0 7} \text { to 00-07-2011 }\end{array}$ \\
\hline \multirow{3}{*}{\multicolumn{2}{|c|}{$\begin{array}{l}\text { 4. TITLE AND SUBTITLE } \\
\text { Range Atmospheric and Oceanic Environmental Support Capabilities }\end{array}$}} & 5a. CONTRACT NUMBER \\
\hline & & 5b. GRANT NUMBER \\
\hline & & 5c. PROGRAM ELEMENT NUMBER \\
\hline \multirow{3}{*}{\multicolumn{2}{|c|}{ 6. $\operatorname{AUTHOR}(\mathrm{S})$}} & 5d. PROJECT NUMBER \\
\hline & & $\begin{array}{l}\text { 5e. TASK NUMBER } \\
\text { MG-020 }\end{array}$ \\
\hline & & 5f. WORK UNIT NUMBER \\
\hline \multicolumn{2}{|c|}{$\begin{array}{l}\text { 7. PERFORMING ORGANIZATION NAME(S) AND ADDRESS(ES) } \\
\text { Range Commanders Council,1510 Headquarters Avenue, White Sands } \\
\text { Missile Range,NM,88002 }\end{array}$} & $\begin{array}{l}\text { 8. PERFORMING ORGANIZATION } \\
\text { REPORT NUMBER } \\
\text { 354-11 }\end{array}$ \\
\hline \multirow{2}{*}{\multicolumn{2}{|c|}{ 9. SPONSORING/MONITORING AGENCY NAME(S) AND ADDRESS(ES) }} & 10. SPONSOR/MONITOR'S ACRONYM(S) \\
\hline & & $\begin{array}{l}\text { 11. SPONSOR/MONITOR'S REPORT } \\
\text { NUMBER(S) }\end{array}$ \\
\hline
\end{tabular}

12. DISTRIBUTION/AVAILABILITY STATEMENT

Approved for public release; distribution unlimited

13. SUPPLEMENTARY NOTES

14. ABSTRACT

Provides identification of individual range capabilities, requirements, procurement, and specialized data sets and databases for natural and oceanic environments.

15. SUBJECT TERMS

Meteorology Group

\begin{tabular}{|c|c|c|c|c|c|}
\hline \multicolumn{3}{|c|}{ 16. SECURITY CLASSIFICATION OF: } & 17. LIMITATION OF & 18. NUMBER & 19a. NAME OF \\
\hline $\begin{array}{c}\text { a. REPORT } \\
\text { unclassified }\end{array}$ & $\begin{array}{c}\text { b. ABSTRACT } \\
\text { unclassified }\end{array}$ & $\begin{array}{c}\text { c. THIS PAGE } \\
\text { unclassified }\end{array}$ & $\begin{array}{c}\text { Same as } \\
\text { Report (SAR) }\end{array}$ & 62 & \\
\hline
\end{tabular}


This page intentionally left blank. 
DOCUMENT 354-11

RANGE ATMOSPHERIC AND OCEANIC ENVIRONMENTAL SUPPORT CAPABILITIES

DECEMBER 2011

Prepared by

METEOROLOGY GROUP

\author{
Published by \\ Secretariat \\ Range Commanders Council \\ U.S. Army White Sands Missile Range \\ New Mexico 88002-5110
}


This page intentionally left blank. 


\section{TABLE OF CONTENTS}

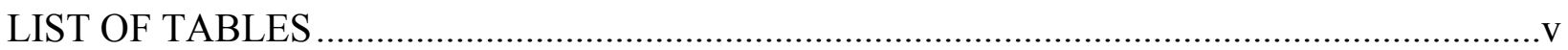

PREFACE

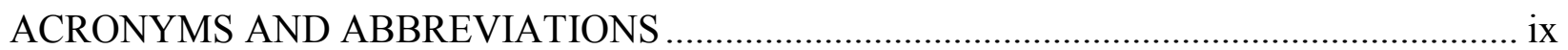

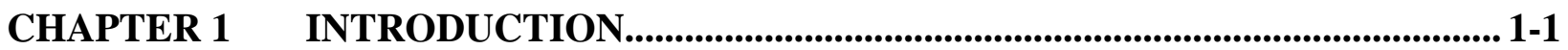

$1.1 \quad$ Purpose

$1.2 \quad$ Scope

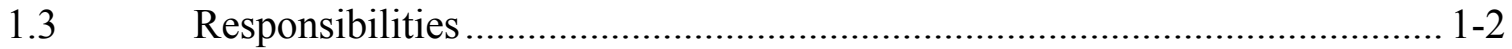

CHAPTER 2 SUMMARY OF ENVIRONMENTAL SUPPORT AT

THE RANGES ..................................................................................................... 2-1

2.1 Natural Environmental Support Available to Range Users ......................... 2-1

2.2 Website Links for Range Weather Information...................................... 2-2

CHAPTER $3 \quad 30^{\mathrm{TH}}$ SPACE WING ......................................................................... 3-1

Introduction................................................................................... $3-1$

Weather Instrumentation .................................................................. 3-1

CHAPTER $4 \quad 45^{\text {TH }}$ SPACE WING ............................................................................... 4-1

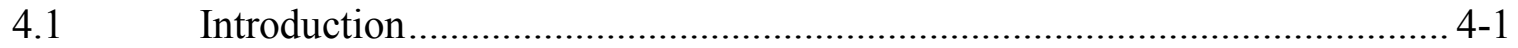

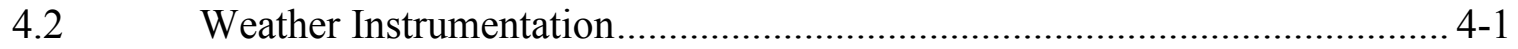

CHAPTER $5 \quad$ ABERDEEN TEST CENTER ..........................................................5 5-1

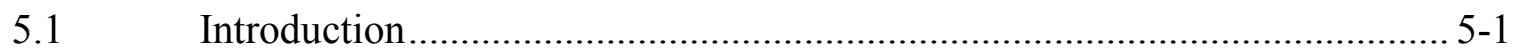

Weather Instrumentation................................................................ 5-1

CHAPTER 6 AIR ARMAMENT CENTER ...............................................................6 6-1

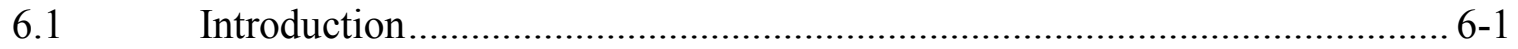

6.2 Weather Instrumentation................................................................... 6-2

CHAPTER 7 AIR FORCE FLIGHT TEST CENTER..................................................... 7-1

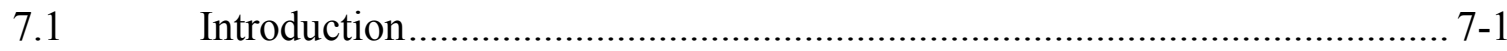

Weather Instrumentation................................................................. 7-1

CHAPTER 8 ELECTRONIC PROVING GROUND ................................................... 8-1

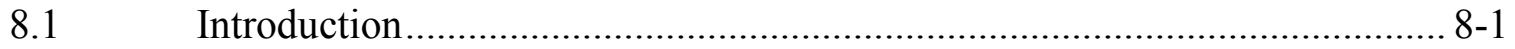

Weather Instrumentation ................................................................. 8-1

CHAPTER 9 NASA DRYDEN..................................................................................9 9-1

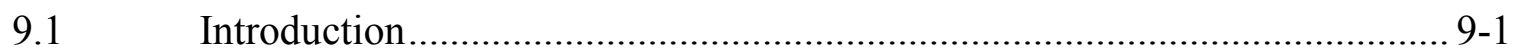

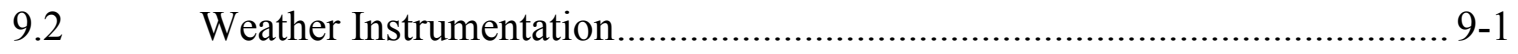

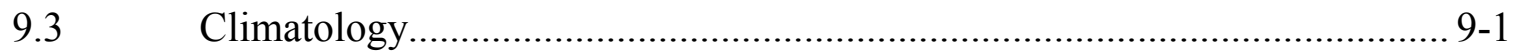


CHAPTER 10 NASA KENNEDY SPACE CENTER .......................................................10-1

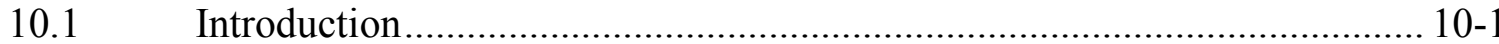

$10.2 \quad$ Weather Instrumentation......................................................... 10-1

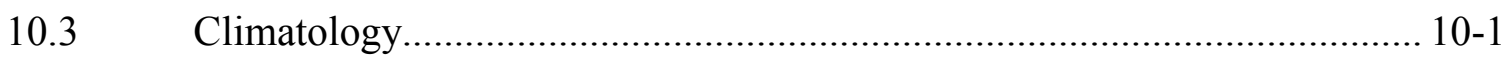

CHAPTER 11 NAVAL AIR WARFARE CENTER WEAPONS DIVISION, ATLANTIC TEST RANGE......................................................................... 11-1

$11.1 \quad$ Introduction.................................................................................... 11-1

$11.2 \quad$ Weather Instrumentation................................................................ 11-1

CHAPTER 12 NAVAL AIR WARFARE CENTER WEAPONS DIVISION, CHINA LAKE ..................................................................................12-1

$12.1 \quad$ Introduction...................................................................................... 12-1

$12.2 \quad$ Weather Instrumentation................................................................ 12-1

CHAPTER 13 NAVAL AIR WARFARE CENTER WEAPONS DIVISION, POINT MUGU ...............................................................................13-1

$13.1 \quad$ Introduction................................................................................... 13-1

$13.2 \quad$ Weather Instrumentation................................................................ 13-1

CHAPTER 14 PACIFIC MISSILE RANGE FACILITY .................................................. 14-1

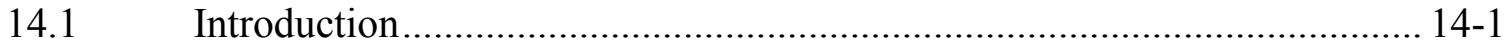

$14.2 \quad$ Weather Instrumentation.............................................................. 14-1

CHAPTER 15 REAGAN TEST SITE ........................................................................15-1

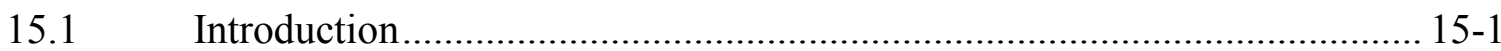

$15.2 \quad$ Weather Instrumentation....................................................................... 15-1

CHAPTER 16 WHITE SANDS MISSILE RANGE ….................................................... 16-1

$16.1 \quad$ Introduction................................................................................. 16-1

$16.2 \quad$ Weather Instrumentation................................................................. 16-2

CHAPTER 17 WRIGHT-PATTERSON AFB ................................................................. 17-1

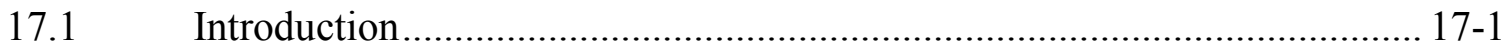

$17.2 \quad$ Instrumentation ........................................................................... 17-1

CHAPTER 18 YUMA PROVING GROUND ….......................................................... 18-1

$18.1 \quad$ Introduction................................................................................. 18-1

$18.2 \quad$ Weather Instrumentation................................................................ 18-1 


\section{LIST OF TABLES}

Table No.

Page No.

Table 2-1. Various Range Weather Websites ............................................................... 2-3

Table 3-1. $\quad 30^{\text {th }}$ Space Wing Climatology ...................................................................... 3-3

Table 4-1. $\quad 45^{\text {th }}$ Space Wing Climatology ..................................................................... 4-2

Table 5-1. Aberdeen Test Center Climatology …...................................................... 5-3

Table 6-1. Air Armament Center Climatology …....................................................... 6-3

Table 7-1. Air Force Flight Test Center Climatology .................................................... 7-2

Table 8-1. Electronic Proving Ground Climatology ........................................................... 8-1

Table 11-1. Naval Air Warfare Center Weapons Division, Atlantic Test

Range Climatology ............................................................................ 11-2

Table 12-1. Naval Air Warfare Center Weapons Division, China Lake Climatology............. 12-2

Table 13-1. Naval Air Warfare Center Weapons Division, Point Mugu ............................... 13-2

Table 14-1. Pacific Missile Range Facility ................................................................. 14-1

Table 15-1. Reagan Test Site Climatology ...................................................................... 15-2

Table 16-1. White Sands Missile Range Climatology ................................................... 16-3

Table 17-1. Wright-Patterson Air Force Base Climatology ............................................ 17-2

Table 18-1. Yuma Proving Ground Climatology .......................................................... 18-2 
Range Atmospheric and Oceanic Environmental Support Capabilities, RCC Document 354-11, December 2011

This page intentionally left blank. 


\section{PREFACE}

The Meteorology Group (MG) of the Range Commanders Council (RCC) has prepared this document to provide updated information on range atmospheric and oceanic environmental support capabilities in answer to Task MG-020. The previous version was last updated in 1992, and technology, reorganizations, and changing customer base require updates to the shared capabilities and documentation. This document will serve as a tool for long range test planning for range customers.

The RCC would like to provide special thanks to the following individual for the development of this document.

Task Lead: $\quad$ Mr. Lynn Rose

Reagan Test Site

Atmospheric Technology Services Co.

P.O. Box 3029

Norman, OK 73070-3029

Phone: (405) 325-0056 Ext. 2

Fax (405) 325-2005

E-mail: r.lynn.rose@us.army.mil

The MG will appreciate constructive criticism to assist in improving the document content. Correspondence may be addressed to the RCC Secretariat at:

Secretariat, Range Commanders Council

ATTN: TEDT-WS-RCC

100 Headquarters Avenue

White Sands Missile Range, New Mexico 88002-5110

Phone: (575) 678-1107 DSN 258-1107

Fax: $\quad$ (575) 678-9517 DSN 258-9517

E-mail: $\quad$ usarmy.wsmr.atec.list.rcc@mail.mil 
Range Atmospheric and Oceanic Environmental Support Capabilities, RCC Document 354-11, December 2011

This page intentionally left blank. 


\section{ACRONYMS AND ABBREVIATIONS}

4DLSS

4DWx

AAC

AFB

AFSOC

ALDF

AN/FMQ

AMPS

APG

ARL

ASOS

ATC

ATEC

ATR

AWIPS

AWOS

BLAST

CCAFS

CGLSS

COAMPSOS

CONUS

DAS

DASS

DBASI

DoD

DRWP

EO-DCP

EOD

EPG

FDE

FMQ

FNMOC

GOES

GPS

ICBM

IR

IRIG

IDV

IWDS

JAAWIN

JSC

JSF

$\mathrm{km}$
Four Dimensional Lightning Surveillance System

Four Dimensional Weather System

Air Armament Center

Air Force Base

Air Force Special Operations Command

Aircraft Landing Dynamics Facility

Army Navy Fixed Meteorological Equipment

Automated Meteorological Profiling System

Aberdeen Proving Ground

Army Research Laboratory

Automated Surface Observation Station

Aberdeen Test Center

Army Test and Evaluation Command

Atlantic Test Range

Advanced Weather Interactive Processing System

Automated Weather Observation Station

Battlefield Laser Acquisition Sensor Test

Cape Canaveral Air Force Station

Cloud-to-Ground Lightning Surveillance System

Coupled Ocean Atmosphere Mesoscale Prediction System Operating

Software

Continental United States

Data Acquisition Systems

Doppler Acoustic Sounding System

Digital Barometer Altimeter Setting Indicator

Department of Defense

Doppler radar wind profiler

Electro Optics Data Collection Platform

Explosive Ordnance Disposal

Electronic Proving Ground

Force Development Evaluation

Fixed Meteorological Equipment

Fleet Numerical Meteorological Oceanography Center

Geostationary Operational Environmental Satellite

Global Positioning System

intercontinental ballistic missile

infrared

Inter-range Instrumentation Group

Interactive Data Visualization

Improved Weather Dissemination System

Joint Air Force Army Weather Information Network

Johnson Space Center

Joint Strike Fighter

kilometers 


\begin{tabular}{|c|c|}
\hline KSC & Kennedy Space Center \\
\hline LIDAR & Lightning Detection and Ranging System \\
\hline LLPS & Local Lightning Position System \\
\hline LOADS & NASA Launch Payload \\
\hline MEF & Mission Execution Forecast \\
\hline MET & Meteorological Team \\
\hline METAR & Meteorological Terminal Aviation Routine Weather Report \\
\hline METEOSAT & Meteorological Satellite \\
\hline MG & Meteorology Group \\
\hline $\mathrm{MHz}$ & megahertz \\
\hline MMS & Magnetospheric Multiscale Mission System \\
\hline MRRD & Multiple Region Radar Display \\
\hline MRTFB & Major Range and Test Facility Base \\
\hline NASA & National Aeronautics and Space Administration \\
\hline NAPS & Noise Assessment and Prediction System \\
\hline NAWC-WD & Naval Air Warfare Center Weapons Division \\
\hline NCAR & National Center for Atmospheric Research \\
\hline NEXRAD & Next Generations Radar \\
\hline NLDN & National Lightning Detection Network \\
\hline NM & nautical mile \\
\hline NOAA & National Oceanic and Atmospheric Administration \\
\hline NOAAport & National Oceanic and Atmospheric Administration broadcast system \\
\hline NWP & National Weather Product \\
\hline NWS & National Weather Service \\
\hline OPUP & Open-user Principle User Processor \\
\hline OWS & Operational Weather Squadron \\
\hline P-RTRDA & Portable Remote Transmission Data Acquisition System \\
\hline PMRF & Pacific Missile Range Facility \\
\hline RADCAL & Radar Calibration \\
\hline RAWS & Remote Automated Weather Station \\
\hline RCC & Range Commanders Council \\
\hline RDT\&E & Research, Development, Test, and Evaluation \\
\hline RFC & River Forecast Center \\
\hline ROAB & radiosonde observation \\
\hline RPG & Radar Product Generator \\
\hline RSA & Company founded by Ron Rivest, Adi Shamir, and Lenard Adleman \\
\hline RTAMPS & Realtime Automated Meteorological Profiling System \\
\hline RT-FDDA & Realtime Four-Dimensional Data Assimilation \\
\hline RTRDA & Remote Transmission Data Acquisition System \\
\hline SAMS & Surface Atmospheric Measuring Systems \\
\hline SESI & Science and Engineering Services Inc \\
\hline SLC & Space Launch Complex \\
\hline SODAR & Sound Detection and Ranging System \\
\hline SPCS & Space Control Squadron \\
\hline SSN & Space Surveillance Network \\
\hline SW & Space Wing \\
\hline
\end{tabular}


$T \& E$

TMQ

UAS

U.S.

VAD

VAFB

VHF

WBGT

WR

WRF

WS

WSR

Wx test and evaluation

Tactical Meteorological Equipment

unmanned aircraft system

United States

Vertical Access Data

Vandenberg Air Force Base

very high frequency

Wet Bulb Globe Temperature

Western Range

Weather Research Forecast

Weather Squadron

Weather System Radar

weather 
Range Atmospheric and Oceanic Environmental Support Capabilities, RCC Document 354-11, December 2011

This page intentionally left blank. 


\section{CHAPTER 1}

\section{INTRODUCTION}

\subsection{Purpose}

The objective of the Range Commanders Council (RCC) is to enhance the national capability for research, development, test, and evaluation (RDT\&E) at member ranges. To implement this objective, the RCC technical and operational groups seek to improve the overall responsiveness, efficiency, effectiveness, and economical operation of the member ranges, individually and collectively. The Meteorology Group (MG) is concerned with improving the capabilities of range geophysical agencies to define the effects of atmospheric and oceanic parameters on aeronautical, marine, missile, and space systems. The MG focuses its efforts on the instrumentation and techniques used to measure, predict, and evaluate these effects and on improving overall environmental support to range activities and users.

\subsection{Scope}

An important aspect of the MG's work is identifying support capabilities and requirements for natural atmospheric and oceanic environments. These capabilities and requirements must satisfy present and projected needs. Planned procurement by individual ranges showing equipment upgrades and possible equipment excess will foster exchanges, transfers, joint procurements, and cost savings to all member ranges. Equipment in excess of individual range requirements is announced in the range report. Specialized data sets and data bases are identified in this publication for the same reasons as planned procurement. This document represents a current identification of individual range capabilities, requirements, procurement, and specialized data sets and databases. This document supersedes RCC Document 354-92, Range Atmospheric and Oceanic Environmental Support Capabilities, Requirements, and Procurement, which is obsolete and should be destroyed.

The ranges have limited resources to meet the objective of enhancing national capabilities for development and test support. In updating range facilities in support of this objective, the $\mathrm{RCC}$ is concerned with where to place these limited resources for research and development and with procurement of instrumentation. This document was prepared to assist in the determination of atmospheric and oceanic priorities and to consolidate and publicize participating ranges and geophysical capabilities.

The statement of true requirements for data and services is a prerequisite for determining the solutions to the above concerns. Therefore, the RCC has a continuing and pressing need to maintain current, validated statements of range and user requirements for natural atmospheric and oceanic environmental services. Satisfaction of that need is complicated by the wide variation of services required, the diversity in programs supported, and the governmental agencies and contractors involved in those programs. 
Secondary in importance, but vital, is the identification of the requirements for instrumentation and techniques to measure the physical environments in which future systems will operate.

In 1969, to meet the need for requirements statements, the RCC directed the MG to update Inter-range Instrumentation Group (IRIG) Document 108-64, Range Users Meteorological Requirements. The MG formed a committee to revise that document under the expanded concept of range and user needs for natural environmental support. The revision was to include not only requirements for meteorology, but also the needs in such related fields as aeronomy, climatology, geophysics, oceanography, and atmospheric physics. This committee developed RCC Document 125-72 to support this task assignment. In 1978, the MG determined that RCC Document 125-72 needed to be updated and expanded to include capabilities of the member ranges and requirements for range management and a management indicator program for determining their shortfalls and overkills. The committee added planned procurement and equipment excess to requirements for promulgation, joint procurement, and cost savings. In 1980, this publication was reissued as RCC Document 125-80, and then renumbered to RCC Document 354-80. Page changes were provided by individual ranges in 1983. This update drops the equipment excess section because it is now identified in individual range activity reports and added data sets and databases. In 1992, this publication was updated as RCC Document 354-92, Range Atmospheric and Oceanic Environmental Support Capabilities, Requirements, and Procurement.

\subsection{Responsibilities}

This document will provide the RCC with a satisfactory basis to plan for the modernization, exchange, joint development and procurement of the instruments, techniques, and services required to meet new demands. Therefore the RCC will be better able to maintain a balanced and standardized interrange capability to respond to new testing community needs community.

Today's atmospheric and oceanic environmental sciences are unable to completely match the ranges' needs for definitive information and predictive capability. Because existing data and current theoretical models are inadequate, areas of development and test application exist in which range users can be offered no more than qualitative interpretations. Within the framework of these limitations, requirements frequently are stated by users in terms of available equipment. At times, the true but unstated requirements are more stringent and cannot be met by present equipment: therefore, it is important to distinguish between the requirements that can and cannot be met. Thus, this document should furnish a basis for initiating exploratory and advanced development of needed range instrumentation, thereby contributing to the process of range modernization. Two important areas strongly related to range requirements were not investigated and therefore not included in this document. No attempt was made to assess dollar values to different testing processes or to determine which combinations might be optimum for evaluation purposes. These areas are elaborated on in the following paragraphs:

a. In cases of stated user requirements that are in excess of present capabilities, costbenefit ratios for atmospheric and oceanic environmental data need to be developed. Such ratios would serve to quantify the percentage increase in effectiveness of an 
operation, or the percentage decrease in operational costs. The ratios would be acquired through a process of development and acquisition of new instrumentation and techniques to meet expanded requirements. This development and procurement process may, in some instances, be hampered by competition with other needs of the development and testing functions, by the difficulty in assessing intangible benefits of improved reliability, and by the degree to which overall austerity prevails in a given funding cycle. These factors may delay the improvement of environmental measurement systems; however, the capability to adequately measure the natural environment in which tests and operations are conducted. These consequences of delays would be high risks in weapon systems decisions, where mistakes can be far more costly than a new data system or improved range facility. Modernization decisions can be improved by developing and using cost-benefit ratios for atmospheric and oceanic environmental data.

b. The optimum interface of various combinations of instrumentation must be determined and advantageous tradeoffs delineated. Typical combinations are atmospheric and oceanic data-gathering satellites with surface, rocketsonde, rawinsonde, wind profiler, and buoy-observational stations. Investigations into tradeoffs can answer such questions as whether or not satellites or ground-based indirect sensing will provide enough cloud information to supplant surface observations of cloud type and amount, or if they will provide enough information about vertical profiles of wind and thermodynamic variables to take the place of direct probing by Doppler radar or balloon and rocket soundings. Answers to these types of questions are important, for they may determine if test-site stations can be completely automated to provide more effective and less costly service to range users.

The MG committee believes this document will also be extremely valuable to the test and evaluation (T\&E) community when selecting appropriate sites for required system tests. Range users and program planners will be in a better position to plan their tests at minimum cost if they have knowledge of all the major ranges' present and planned atmospheric and oceanic environmental capabilities and climatology. Standard error (accuracy) estimates for meteorological data currently furnished to users at the major ranges are contained in RCC Document 353-87, Meteorological Data Error Estimates. 
Range Atmospheric and Oceanic Environmental Support Capabilities, RCC Document 354-11, December 2011

This page intentionally left blank. 


\section{CHAPTER 2}

\section{SUMMARY OF ENVIRONMENTAL SUPPORT AT THE RANGES}

\subsection{Natural Environmental Support Available to Range Users}

From the moment an environmentally sensitive item is identified until it is finally delivered to the using agency, the natural atmospheric and oceanic environment effects must be considered. These effects fall into four general classes. First, the environment in which the item is expected to operate will influence both its design and its development. Second, the condition of the natural environment at the test site will directly affect the way an item test is conducted as well as the performance of the item during the test. These effects require prior establishment of environmental criteria for the test and of environmental test objectives. Third, the temporal and spatial changes of the environment during the test must be measured at the test site. Finally, the measured effect of the environment on the test item's performance must be evaluated.

For the above reasons, the test range geophysical agencies have responsibilities to their respective agencies and customers to ensure that the atmospheric and oceanic environments are fully considered in the design and development of a test. They also strive to guarantee that appropriate environmental criteria are set for tests, that these criteria are met with an adequate collection of environmental test data, and that all aspects of the environments are taken into account during the evaluation of these tests.

In the course of fulfilling these four primary responsibilities, test range meteorologists can provide a variety of services to governmental agencies and authorized contractors. The major ranges' geophysical agencies may do the following:

a. Provide Developmental Planning Consultant Services. When given a requirement for a system to eliminate a particular threat, the agencies summarize the environmental envelopes within the possible theaters of operation for decisions involving general classes of guidance and delivery systems. They provide detailed inputs of average and extreme ranges of environmental parameters affecting system components. The agencies furnish values of persistence, predictability, and climatological frequency of operationally critical atmospheric and oceanic parameters to determine operability, optimum mix systems, or both. They also specify the extent of natural atmospheric and oceanic environmental limitations to systems.

b. Furnish Test Planning Consulting Services. The geophysical agencies identify the environmental sensitivities of components, systems, and techniques proposed for acquisition and testing. The agencies specify the conditions under which environment-sensitive items must be tested and the environmental components that must be collected during testing. For laboratories, geophysical agencies identify the areas where environmental data deficiencies will degrade the quality and effectiveness of developmental programs. They provide government agencies and contractors with climatological planning studies of the various range environments for use in selecting candidate ranges for systems testing. For T\&E organizations, the geophysical agencies identify the areas where the lack of adequate environmental 
databases will reduce reliability of test programs. The agencies aid in the preparation of environmental impact-of-testing statements in test documentation. They provide needed consultation for selection and documentation of the best approach to collecting environmental data for individual tests and give advice on possible tradeoffs to overcome any environmental degradation of test-item performance. The agencies specify the geophysical equipment and facilities that require updating to provide and to maintain a viable range capability for testing in the atmospheric and oceanic environment.

c. Provide Data Acquisition and Forecast Services. The geophysical agencies gather atmospheric and oceanic environmental data during tests. The data is provided in the manner of measurements of normal and specialized environmental parameters at ground level, on towers, by indirect sensing (including the use of satellites), and by physical probing of the atmosphere to altitudes reaching 100 kilometers. Using current test site data, the resources of the National Weather Service and Department of Defense (DoD) weather services, and the facilities of a fully equipped weather station, the geophysical agencies provide close forecasting support to individual range projects.

d. Perform Evaluation Services. The agencies evaluate and analyze atmospheric and oceanic environmental effects on performance of items during testing. They assess relative merits of competing systems from the environmental standpoint and assist in defining engineering design action and alterations needed to optimize system effectiveness with respect to the natural environment. After tests are completed, the agencies also aid in the preparation of environmental data for reports.

\subsection{Website Links for Range Weather Information}

Table 2-1 provides a list of some range websites that may be accessed to review specific range weather data and related information. 
TABLE 2-1. VARIOUS RANGE WEATHER WEBSITES

\begin{tabular}{|c|c|}
\hline Range & Web Address \\
\hline $\begin{array}{l}\text { Aberdeen Test Center, } \\
\text { MD }\end{array}$ & http://www.atc.army.mil/weather/ \\
\hline $\begin{array}{l}\text { Dugway Proving } \\
\text { Ground, UT }\end{array}$ & http://www.dugway.army.mil/index.php/index/content/id/194 \\
\hline Edwards AFB, CA & https://bsx.edwards.af.mil/weather/ \\
\hline $\begin{array}{l}\text { NASA Johnson Space } \\
\text { Flight Center, Houston, } \\
\text { TX }\end{array}$ & http://www.srh.noaa.gov/smg/ \\
\hline $\begin{array}{l}\text { NASA Kennedy Space } \\
\text { Center, FL }\end{array}$ & http://science.ksc.nasa.gov/weather/weather.html \\
\hline $\begin{array}{l}\text { NASA Marshall Space } \\
\text { Flight Center, AL }\end{array}$ & http://wwwghcc.msfc.nasa.gov/ \\
\hline $\begin{array}{l}\text { NAVAIR China Lake } \\
\text { and Pt. Mugu, CA }\end{array}$ & http://www.navair.navy.mil/nawcwd/weather/home1.htm \\
\hline $\begin{array}{l}\text { NAVAIR } \\
\text { Patuxent River, MD }\end{array}$ & $\begin{array}{l}\text { https://mynavair.navair.navy.mil/portal/server.pt/community/atlantic } \\
\text { test_range weather/1432 } \\
\text { Note: Requires user name and password }\end{array}$ \\
\hline Patrick AFB, FL & http://www.patrick.af.mil/weather/index.asp \\
\hline RTS (Kwajalein) & $\underline{\text { http://www.rts-wx.com/ }}$ \\
\hline $\begin{array}{l}\text { White Sands } \\
\text { Missile Range, NM }\end{array}$ & https://wsmrc2vger.wsmr.army.mil/weather/public/forecast.htm \\
\hline
\end{tabular}


Range Atmospheric and Oceanic Environmental Support Capabilities, RCC Document 354-11, December 2011

This page intentionally left blank. 


\section{CHAPTER 3}

\section{$30^{\mathrm{TH}}$ SPACE WING}

\subsection{Introduction}

The Western Range (WR) was established by the DoD to provide spacecraft processing, launch and tracking facilities for DoD, civil, commercial and foreign customers. The WR extends west from the coast of California towards the Indian Ocean providing realtime range operations for space launch, intercontinental ballistic missile (ICBM) Force Development Evaluation (FDE) testing, aeronautical, aerospace, and other approved programs. In addition, the WR operates the Radar Calibration (RADCAL) satellite program for all national ranges and the Space Surveillance Network (SSN). As a member of a major range and test facility base (MRTFB), the WR can request support from other MRTFB member ranges. In addition, MRTFB member ranges can request support from the WR for their operational programs. The $\mathrm{RCC}$ establishes a single point of contact policy for customers requiring support from multiple ranges.

The WR provides telemetry acquisition, metric tracking, command control, short and long range photo optics, area surveillance, meteorological forecasts, communications, realtime data processing, and post-flight data production.

Vandenberg has a hosted MM5 $1.1 \mathrm{~km}$ scale forecasting model developed by National Weather Service (NWS) Environmental Systems Research Laboratory for highly specified terrain affected modeling used for launch operation meteorological decisions.

\subsection{Weather Instrumentation}

a. Weather Radar: Doppler

(1) Specifics: The Weather System Radar (WSR)-88D Next Generations Radar (NEXRAD) generates three base products: reflectivity, velocity, and spectrum width. From these products, the Radar Product Generator (RPG) generates a wide variety of "derived" products, which, in addition to the base products, the Range Forecasters and Launch Weather Officers can use to monitor, analyze, and track significant weather events out to a range of up to 248 nautical miles (NM).

(2) Purpose: Daily range operations, and $30^{\text {th }}$ Space Wing missions. Vandenberg Air Force Base (VAFB) is unique in that the WSR-88 NEXRAD is owned, maintained, and operated by VAFB.

(3) Uses: Precipitation location/intensity, thunderstorm location/intensity, rainfall/flash flood warning, hydrometer characterization, wind warnings, and wind shear and turbulence forecasting.

b. Satellite: Geostationary Operational Environmental Satellite (GOES)-11 and GOES-12. Receive feed from: satellite feed from National Oceanic and Atmospheric Administration (NOAA) broadcast system (NOAAPort) through Advanced Weather Interactive Processing System (AWIPS) display system. 
c. Upper Air: radiosondes, sonic profiler, radar profiler. Specifics: capable of ten simultaneous radiosondes. Mini-Sound Detection and Ranging System (SODAR): range 15-150 meters, six sites. 915 Megahertz (MHz) Doppler radar wind profiler (DRWP): range 120-3000 meters, six sites, $50 \mathrm{MHz}$ DRWP, range 2,500-20,000 meters, one site.

d. Surface:

(1) Ceilometer: Automated Surface Observation Station (ASOS).

(2) Rain Gauge: ASOS.

(3) Anemometer: ASOS plus 26 wind towers located across the Western Range.

(4) Manual Surface Observations: Digital Barometer Altimeter Setting Indicator (DBASI), Kestrel, Aneroid barometer, manual observing kit, and a Tactical Meteorological Equipment (TMQ)-53.

(5) Automated Weather Observation Station (AWOS)/ASOS: Three ASOS sensors, north and south base, and airfield north base ASOS is only partially instrumented. Cloud height, visibility, precipitation identification (airfield and south base), freezing rain (airfield and south base), pressure, temperature dew point (airfield and south base), wind direction and speed (airfield and south base), precipitation accumulation (airfield and south base).

(6) Other: Vandenberg has 8 wind towers instrumented with soil moisture sensors and solar irradiance monitors at selected sites.

e. Lightning System: National Lightning Detection Network (NLDN) Data, Sensor Network, Local Lightning Position System (LLPS). Specifics: Lightning Location and Protection System (Primary) with four aircraft landing dynamics facility (ALDF) sensor networks. This is slated to be upgraded to a total lightning network in 2011.

f. Other instruments used in support of weather related efforts:

(1) Doppler Acoustic Sounding System (DASS) is capable of measuring the atmospheric temperature structure, boundary layer profiles and vector wind components, in 50-meter increments, up to 1000 meters. North base and near the airfield.

(2) The Automated Meteorological Profiling System (AMPS) tracks two types of expendable balloons: hi-resolution and lo-resolution sondes. The Realtime Automated Meteorological Profiling System (RTAMPS) receives input data from the AMPS. The RTAMPS computes from the AMPS data standard meteorological data and make this data available for Range users. The meteorological data produced are mean winds, regional winds, thermodynamic data, perceptible water, mandatory and significant levels, conventional tropopause and Showalter stability index.

(3) The RSA (company founded by R Rivest, A Shamir, and L Adleman) wind towers consist of 26 towers placed in strategic locations throughout the range. The standard $54 \mathrm{ft}$ towers employ a variety of sensors at the 6,12 and $54 \mathrm{ft}$ levels. Sensors consist of Vaisala 425 Ultrasonic Wind Sensors (sonic anemometers), which use ultrasound to determine horizontal wind speed and direction. Eight strategically selected towers measure soil moisture content and incoming and outgoing radiation. Every location has temperature sensors at both the lower and upper levels. Designated tall towers, so-called because they are taller than the standard 54 feet and consisting of Towers 54 at Space Launch complex (SLC)-03, 
102 at SLC-02, 300 at SLC-04 and 301 at SLC-06, contain sensors at various levels up to a height of 300 feet (Towers 300 and 301). Data from each tower is broadcast every minute and processed on a Linux-based server and then sent to the AWIPS file server at the weather station where it is available for display on the same AWIPS workstations as national weather data.

(4) In addition to tall towers, wind data is available from a suite of six co-located $915 \mathrm{MHz}$ Boundary Layer DRWP and mini SODARs placed at strategic launch areas on VAFB. Together, both systems provide wind and temperature data from the surface to $4 \mathrm{~km}$ aloft.

\begin{tabular}{|c|c|c|c|c|c|c|c|c|c|c|}
\hline \multicolumn{11}{|c|}{ TABLE 3-1. $30^{\text {th }}$ SPACE WING CLIMATOLOGY } \\
\hline \multirow{3}{*}{ Month } & \multirow{2}{*}{\multicolumn{3}{|c|}{$\begin{array}{c}\text { Winds (knots) } \\
\text { Prevailing }\end{array}$}} & \multicolumn{5}{|c|}{ Temperature $\left({ }^{\circ} \mathrm{F}\right)$} & \multicolumn{2}{|c|}{ Precip (inches) } \\
\hline & & & & \multirow{2}{*}{$\begin{array}{l}\text { Abs } \\
\text { Max }\end{array}$} & \multirow{2}{*}{$\begin{array}{l}\text { Avg } \\
\text { Max }\end{array}$} & \multirow{2}{*}{ Avg } & \multirow{2}{*}{ Avg } & \multirow{2}{*}{$\begin{array}{l}\text { Abs } \\
\text { Min }\end{array}$} & \multirow{2}{*}{$\begin{array}{c}\text { Mon } \\
\text { Avg }\end{array}$} & \multirow{2}{*}{$\frac{24 \mathrm{hr}}{\mathrm{Max}}$} \\
\hline & Dir & Speed & Peak & & & & & & & \\
\hline Jan & NNW & 11.5 & 50.9 & 90 & 62 & 52 & 44 & 25 & 2.8 & 2.5 \\
\hline Feb & NNW & 12.2 & 55.9 & 86 & 62 & 53 & 46 & 31 & 3.1 & 3.1 \\
\hline Mar & NNW & 13.2 & 43.9 & 87 & 62 & 53 & 48 & 32 & 2.7 & 3.5 \\
\hline Apr & NNW & 13.4 & 47.0 & 102 & 62 & 54 & 48 & 32 & 1.1 & 3.1 \\
\hline May & NNW & 13.0 & 41.0 & 92 & 63 & 55 & 51 & 37 & 0.3 & 2.1 \\
\hline Jun & NNW & 11.1 & 39.0 & 104 & 65 & 57 & 53 & 42 & 0.1 & 0.7 \\
\hline Jul & NW & 9.7 & 36.9 & 88 & 67 & 58 & 55 & 45 & 0.0 & 0.2 \\
\hline Aug & NW & 8.5 & 36.9 & 96 & 67 & 59 & 55 & 45 & 0.1 & 0.9 \\
\hline Sep & NNW & 9.3 & 35.9 & 98 & 68 & 59 & 54 & 41 & 0.2 & 1.7 \\
\hline Oct & NW & 9.9 & 41.0 & 99 & 68 & 58 & 52 & 35 & 0.6 & 1.5 \\
\hline Nov & NNW & 10.9 & 51.9 & 91 & 66 & 56 & 49 & 30 & 1.6 & 2.5 \\
\hline Dec & NNW & 12.2 & 42.0 & 87 & 62 & 53 & 45 & 23 & 1.9 & 3.3 \\
\hline Ann & NNW & 11.1 & 55.9 & 104 & 65 & 56 & 50 & 23 & 14.3 & 3.5 \\
\hline
\end{tabular}


Range Atmospheric and Oceanic Environmental Support Capabilities, RCC Document 354-11, December 2011

This page intentionally left blank. 


\section{CHAPTER 4}

\section{$45^{\mathrm{TH}}$ SPACE WING}

\subsection{Introduction}

The $45^{\text {th }}$ Space Wing (45 SW) is a United States Air Force unit stationed at Patrick Air Force Base (AFB), FL. Meteorological support is one of the range services that is the responsibility of the $45 \mathrm{SW}$.

Seven days a week, twenty four hours a day, service is provided for weather watches, warnings and advisories. These include lightning watches and warnings, convective wind warnings, temperature advisories, tornado warnings, and notice of hail of any size.

During space launch, there are services for evaluation and prediction of lightning launch commit criteria as well as use launch commit criteria. The meteorology support group also provides guidance to the LOADS (NASA launch payload) community and to Range Safety for toxic dispersion, debris, and Battlefield Laser Acquisition Sensor Test (BLAST). During ground processing, the meteorology support team provides evaluation and prediction of mission weather constraints such as lightning distance thresholds, wind thresholds, etc. During special missions, evaluation and prediction of mission weather constraints such as lightning distance thresholds and wind thresholds are provided.

\subsection{Weather Instrumentation}

a. Weather Radar: Doppler

(1) Specifics: WSR-74C conventional C-band radar at Patrick AFB. WSR-88D Doppler radar NWS Melbourne.

(2) Purpose: Daily range operations, and missions. Radar is used in almost all 45 Weather Squadron (WS) missions launch, pre-launch ground processing, weather watches/warnings/advisories, personnel safety and resource protection, aviation support, and forecasting.

(3) Uses: precipitation location/intensity, thunderstorm location/intensity, lightning monitoring, rainfall/flash flood warning, and wind warnings.

(4) Other: Radar affects most aspects of 45 WS operations including: evaluation of lightning launch commit criteria, lightning watches and warnings, convective wind warnings, tornado and other severe weather warnings, hail warnings, general weather surveillance, and others.

b. Satellite: GOES-11, GOES-12 and METEOSAT.

(1) Direct Feed List: GOES-11, GOES-12, GOES-13 (not listed above).

(2) Receive Feed from Other Source List: METEOSAT. Data from all the other satellites can be accessed as needed, but rarely if ever used directly.

c. Upper Air: Radiosondes, Satellite Derived Soundings, Radar Profiler.

Specifics: Local radiosonde at CCAFS, including both low and high resolution versions. Fifty MHz DRWP at KSC. Sounders from GOES and other government satellites. 
d. Surface: ceilometer, rain gauge, and anemometer. Fixed Meteorological Equipment (FMQ)-19 sensor weather observations at Patrick AFB and CCAFS.

e. Lightning Detection:

(1) NLDN Data: Direct satellite feed.

(2) Stand-alone Sensor: Four Dimensional Lightning Surveillance System (4DLSS) which includes the Cloud to Ground Lightning Surveillance System (CGLSS) and the Lightning Detection and Ranging System (LIDAR), for cloud-to-ground lightning and lightning aloft, respectively.

(3) Sensor Network: Weather Information Network Display System.

(4) Other: Commercial service from Weather Bug Total Lightning Network.

f. Other instruments used at your range in support of weather related efforts:

Meteorological Information Data Display System.

g. Specialized NWP model: None for range operations.

\begin{tabular}{|c|c|c|c|c|c|c|c|c|c|c|}
\hline \multicolumn{11}{|c|}{ TABLE $4-1.45^{\text {th }}$ SPACE WING CLIMATOLOGY } \\
\hline \multirow{3}{*}{ Month } & \multirow{2}{*}{\multicolumn{3}{|c|}{$\begin{array}{c}\text { Winds (knots) } \\
\text { Prevailing }\end{array}$}} & \multicolumn{5}{|c|}{ Temperature $\left({ }^{\circ} \mathrm{F}\right)$} & \multicolumn{2}{|c|}{ Precip (inches) } \\
\hline & & & & Abs & Avg & & Avg & Abs & Mon & $24 \mathrm{hr}$ \\
\hline & Dir & Speed & Peak & Max & Max & Avg & Min & Min & Avg & Max \\
\hline Jan & $\mathrm{N}$ & 9.9 & 50.9 & 86 & 71 & 64 & 57 & 25 & 2.2 & 3.8 \\
\hline Feb & $\mathrm{N}$ & 10.3 & 55.0 & 88 & 73 & 66 & 59 & 32 & 2.5 & 4.7 \\
\hline Mar & $E$ & 9.1 & 54.0 & 93 & 77 & 70 & 63 & 29 & 3.0 & 4.1 \\
\hline Apr & $E$ & 9.1 & 50.9 & 96 & 80 & 73 & 67 & 46 & 2.0 & 2.8 \\
\hline May & $\mathrm{E}$ & 10.5 & 53.8 & 97 & 84 & 78 & 72 & 53 & 3.1 & 3.3 \\
\hline Jun & ESE & 9.1 & 63.9 & 99 & 86 & 80 & 75 & 66 & 5.8 & 6.9 \\
\hline Jul & ESE & 8.4 & 59.8 & 99 & 87 & 82 & 77 & 67 & 4.7 & 5.8 \\
\hline Aug & $\mathrm{E}$ & 8.9 & 59.8 & 99 & 88 & 83 & 78 & 68 & 5.0 & 12.4 \\
\hline Sep & $E$ & 9.7 & 52.1 & 95 & 87 & 82 & 77 & 66 & 7.2 & 8.4 \\
\hline Oct & $E$ & 11.1 & 71.9 & 93 & 83 & 78 & 73 & 50 & 5.1 & 7.6 \\
\hline Nov & $\mathrm{N}$ & 9.9 & 45.1 & 91 & 77 & 71 & 66 & 33 & 2.7 & 5.6 \\
\hline Dec & $\mathrm{N}$ & 9.5 & 42.9 & 86 & 72 & 67 & 61 & 24 & 2.2 & 3.4 \\
\hline Ann & $E$ & 9.3 & 71.9 & 99 & 80 & 75 & 69 & 24 & 45.8 & 12.4 \\
\hline
\end{tabular}




\section{CHAPTER 5}

\section{ABERDEEN TEST CENTER}

\subsection{Introduction}

Aberdeen Test Center (ATC), a multipurpose test center with diverse capabilities, is located on Aberdeen Proving Ground next to the Chesapeake Bay in Maryland. There are several directorates at the ATC, part of which include: Warfighter Directorate, Firepower Directorate, Survivability and Lethality Directorate, Plans and Operations Directorate, and the Command Staff.

Meteorological support is provided to all directorates at ATC with daily forecasts, both short and medium range. Other services include:

a. Deploying instrumentation for test support.

b. Maintaining quality of the data and acquisition process.

c. Issuing data reports.

d. Providing test director with critical info (crosswind data, go/no-go).

e. Noise Assessment and Prediction System (NAPS) developed by Army Research Lab (ARL) but used daily by ATC, it is used to forecast the sound propagation generated during the static testing of explosive material. Depends heavily on model input from Four Dimensional Weather (4DWx) to generate an accurate noise representation.

f. Supporting APG Garrison Emergency Operations Center during major weather events

g. Wide variety of weather forecasting, from winter snowstorms to ice storms and summer heat.

\subsection{Weather Instrumentation}

a. Weather Radar: No WSR on site. Aberdeen uses WSR-88D from Sterling, Virginia and WSR-88D from Dover, Delaware for impending weather. We also use a Multiple Region Radar Display (MRRD) for radar, (hourly surface weather observations using Meteorological Terminal Aviation Routing Weather Report (METAR), and CG lightning data. More information related to the CG lightning data is included below.

(1) Purpose: Daily range operations. Primarily used for forecasting and to issue any advisories/warnings (lightning, flooding, wind, etc.)

(2) Uses: Precipitation location and intensity, thunderstorm location and intensity, lightning monitoring, as well as rainfall/flash flood warnings.

(3) Specifics: As mentioned above, included in the MRRD product is CG lightning data, provided via WeatherBug. The CG data gets routed through our NOAAPort PC, however, it is not part of the NOAAPort data feed. Data gets routed via a Perl script that connects to the WeatherBug server. ASCII file, CONUS data coverage.

b. Satellite: GOES-11, GOES-12. Receive feed from other source list: satellite feed from NOAAPort through NMAP2 display (or optional IDV product). 
c. Upper Air: Radiosondes, sonic profiler, LIDAR profiler. Specifics listed below:

(1) RS-92 SGP Radiosonde.

(2) SODAR Atmospheric System Corp, $2800 \mathrm{~Hz}$ Model 3000.

(3) LIDAR: Currently testing prototype by SESI.

d. Surface:

(1) Rain Gauge: 3 tipping buckets, heated in winter.

(2) Anemometer: RM Young \# 05103.

(3) Other: Six SAMS sites that measure temperature, relative humidity, precipitation, wind direction and wind speed, and solar every 15 minutes, 24 hours a day, 7 days a week, 365 days a year. Remote Transmission Data Acquisition Systems (RTRDA) 1 second permanent wind platforms on several ranges are used for wind monitoring and crosswind calculations. Also Portable Remote Transmission Data Acquisition Systems (P-RTRDAS) for temporary setups.

e. Lightning Detection:

(1) NLDN data.

(2) Thorguard, lightning prediction.

(3) Specifics: lightning forecasting at Aberdeen involves taking input from NLDN (LTS-2005, Vaisala), WeatherBug (MRRD), and Thorguard ( $<15 \mathrm{~km}$ range).

f. Other Instruments used in support of weather related efforts:

(1) WBGT (Wet Bulb Globe Temperature)

(2) EO DCP (pyranometer, pyrgeometer, diffuse, soil temp), air temperature, relative humidity, and pressure.

g. Specialized NWP model: 4DWx (Four Dimensional Weather) 2010.v1.1 is an NWP developed by ATEC and NCAR, which includes two model cores: Weather Research Forecast (WRF) and MM5. It is used for each Army range over different domains while assimilating observations via RT-FDDA allowing the model to be nudged toward observed conditions. 


\begin{tabular}{|c|c|c|c|c|c|c|c|c|c|c|}
\hline \multicolumn{11}{|c|}{ TABLE 5-1. ABERDEEN TEST CENTER CLIMATOLOGY } \\
\hline \multirow{3}{*}{ Month } & \multirow{2}{*}{\multicolumn{3}{|c|}{$\begin{array}{c}\text { Winds (knots) } \\
\text { Prevailing } \\
\end{array}$}} & \multicolumn{5}{|c|}{ Temperature $\left({ }^{\circ} \mathbf{F}\right)$} & \multicolumn{2}{|c|}{ Precip (inches) } \\
\hline & & & & \multirow{2}{*}{$\begin{array}{l}\text { Abs } \\
\text { Max }\end{array}$} & \multirow{2}{*}{$\begin{array}{l}\text { Avg } \\
\text { Max }\end{array}$} & \multirow{2}{*}{ Avg } & \multirow{2}{*}{ Avg } & \multirow{2}{*}{$\begin{array}{l}\text { Abs } \\
\text { Min }\end{array}$} & \multirow{2}{*}{$\begin{array}{c}\text { Mon } \\
\text { Avg }\end{array}$} & \multirow{2}{*}{$24 \mathrm{hr}$} \\
\hline & Dir & Spd & Peak & & & & & & & \\
\hline Jan & "W & 8.9 & 58.1 & 66 & 39 & 34 & 29 & -6 & 3.0 & 2.4 \\
\hline Feb & $\mathrm{N}$ & 8.9 & 54.0 & 73 & 42 & 37 & 31 & 1 & 2.7 & 2.0 \\
\hline Mar & $\mathrm{N}$ & 9.9 & 60.0 & 88 & 51 & 45 & 38 & 7 & 3.3 & 3.1 \\
\hline Apr & $\mathrm{E}$ & 8.0 & 46.0 & 92 & 62 & 56 & 47 & 24 & 3.6 & 2.5 \\
\hline May & $\mathrm{E}$ & 8.0 & 59.1 & 95 & 71 & 65 & 56 & 33 & 4.1 & 3.9 \\
\hline Jun & SSW & 8.0 & 54.0 & 97 & 80 & 74 & 66 & 44 & 4.4 & 3.6 \\
\hline Jul & SSW & 8.0 & 48.0 & 100 & 85 & 79 & 71 & 49 & 4.0 & 5.8 \\
\hline Aug & SSW & 8.0 & 56.9 & 98 & 83 & 77 & 70 & 49 & 4.4 & 6.2 \\
\hline Sep & SSW & 8.9 & 54.0 & 97 & 76 & 70 & 62 & 39 & 3.9 & 9.3 \\
\hline Oct & SSW & 8.9 & 67.0 & 90 & 65 & 59 & 50 & 25 & 3.1 & 2.9 \\
\hline Nov & $\mathrm{N}$ & 8.0 & 55.9 & 80 & 54 & 49 & 43 & 20 & 3.3 & 5.8 \\
\hline Dec & NNW & 9.9 & 46.0 & 72 & 44 & 39 & 33 & 3 & 3.6 & 3.3 \\
\hline Ann & $\mathrm{N}$ & 8.9 & 67.0 & 100 & 63 & 58 & 50 & -6 & 43.4 & 9.3 \\
\hline
\end{tabular}


Range Atmospheric and Oceanic Environmental Support Capabilities, RCC Document 354-11, December 2011

This page intentionally left blank. 


\section{CHAPTER 6}

\section{AIR ARMAMENT CENTER}

\subsection{Introduction}

The Air Armament Center (AAC) is headquartered at Eglin Air Force Base, FL, and is responsible for the development, acquisition, testing, deployment and sustainment of airdelivered weapons. The Center plans, directs, and conducts test and evaluation of U.S. and allied air armament, navigation and guidance systems, and command and control systems.

The following meteorological activities are provided for the AAC in support of all missions:

a. Twenty four hours a day, seven days a week human augmented observations are provided at Eglin Main; limited hours at Duke Field (normal).

b. Staff weather support to five test, training, operational wings, and other associated DoD organizations (normal).

c. Schedule/Launching of radiosondes in support of missions requesting UA data (normal).

d. Maintaining the Improved Weather Dissemination System (IWDS) used to provide weather data, advisories, and warnings across the reservation to various customers (normal).

e. Scheduling an onsite observer (contractor) to support weather sensitive missions (special).

f. Weather outlooks to test engineers for weather sensitive missions, such as Fast CookOffs (special).

g. Staff Meteorologist provides onsite support to Fast Cook-Offs (special).

h. Staff Meteorologist provides support to annual Tomahawk tests (special).

i. Specialized support to USA $6^{\text {th }}$ Ranger Training Battalion (normal).

j. BLAST-Noise Support (temporarily suspended) to the Navy Explosive Ordnance Disposal (EOD) School (normal).

k. High frequency forecasts to the $20^{\text {th }}$ Space Control Squadron (SPCS) phased-array radar (normal).

1. Issuing tropical updates tailored for Eglin as needed (special).

m. Daily Mission Execution Forecasts (MEF) support to test flights (normal).

n. Weather support to Air Force Special Operations Command (AFSOC) missions (normal).

o. Pilot-weather briefing support for range test missions (normal).

p. Issuing weather watches, warnings, and observed weather advisories (normal).

q. Climatological support to test engineers/contractors (normal).

r. Data about current national oil spill priority (special). 


\subsection{Weather Instrumentation}

a. Weather Radar: Doppler.

(1) Specifics: WSR-88D located 8 statute miles from eastern boundary of range or 33 statute miles from Eglin Main.

(2) Purpose: Daily range operations. WSR-88D data used primarily for pilot weather briefings; operational weather forecasting; and issuance of watches/ warnings, and observed advisories.

(3) Uses: Precipitation location and intensity, thunderstorm location, intensity and wind warnings: 25 knot (advisory); 35 knot (moderate); 50 knot (severe).

(4) Specifics: Radar controlled by NWS Mobile but we have an Open-user Principle User Processer (OPUP). Flash flood warnings not a local issue with our sandy soil. River flooding products provided by supporting NOAA/River Forecast Center (RFC). Vertical access data (VAD) wind profile data along with convective signatures support wind advisories and warnings.

b. Satellite: GOES-11, GOES-12, METEOSAT and GOES-13.

Receive Feed from Other Source List: satellite feed from NOAAPort. Also, use visual and IR data from "weather.msfc.nasa.gov" for our Improved Weather Dissemination System (IWDS) display.

c. Upper Air: radiosondes.

Specifics: InterMet (iMet-1) 403 MHz Global Positioning System (GPS) radiosondes launched as missions require from a fixed site at Eglin. InDyne Inc., a range contractor, provides mobile low-level sounder and radiosonde support.

d. Surface:

(1) Ceilometer: Army Navy Fixed Meteorological Equipment (AN/FMQ)-19 with 25 K range.

(2) Rain Gauge: AN/FMQ-19. Tipping-bucket - 0.01 inch per tip.

(3) Anemometer: AN/FMQ-19.

(4) Manual Surface Observations List Equipment: Kestrel 4500; manual rain gauge; TMQ-53 (Tactical Meteorological Observation System).

(5) Other: 15 Remote Automated Weather Stations (RAWS) across reservation composed of Model 555 Data Acquisition Systems (DAS). Two minute observations are sent via very high frequency (VHF) radio link. Note: not all sensors are included on each RAWS station.

e. Lightning Detection: NLDN Data and FMQ-19.

Specifics: direct satellite feed of NLDN data. Display lightning data on our IWDS for customers all across the large reservation.

f. Other Instruments used in support of weather related efforts:

(1) RAWS stations include Solar Radiation Sensors.

(2) Three RAWS include water temperature and water level change instruments.

g. Specialized NWP model: none. 
TABLE 6-1. AIR ARMAMENT CENTER CLIMATOLOGY

\begin{tabular}{|c|c|c|c|c|c|c|c|c|c|c|}
\hline \multirow{3}{*}{ Mon } & \multirow{2}{*}{\multicolumn{3}{|c|}{$\begin{array}{c}\text { Winds (knots) } \\
\text { Prevailing }\end{array}$}} & \multicolumn{5}{|c|}{ Temperature $\left({ }^{\circ} \mathrm{F}\right)$} & \multicolumn{2}{|c|}{ Precip (inches) } \\
\hline & & & & \multirow{2}{*}{$\begin{array}{l}\text { Abs } \\
\text { Max } \\
\end{array}$} & \multirow{2}{*}{$\begin{array}{l}\text { Avg } \\
\text { Max }\end{array}$} & \multirow{2}{*}{ Avg } & \multirow{2}{*}{$\begin{array}{l}\text { Avg } \\
\text { Min } \\
\end{array}$} & \multirow{2}{*}{$\begin{array}{l}\text { Abs } \\
\text { Min } \\
\end{array}$} & \multirow{2}{*}{$\begin{array}{l}\text { Mon } \\
\text { Avg } \\
\end{array}$} & \multirow{2}{*}{$\begin{array}{l}24 \mathrm{hr} \\
\text { Max }\end{array}$} \\
\hline & Dir & Spd & Peak & & & & & & & \\
\hline Jan & $\mathrm{N}$ & 8.0 & 49.9 & 78 & 62 & 54 & 44 & 6 & 4.4 & 5.5 \\
\hline Feb & $\mathrm{N}$ & 7.4 & 46.8 & 81 & 65 & 56 & 46 & 14 & 4.6 & 5.9 \\
\hline Mar & $\mathrm{N}$ & 7.0 & 73.0 & 86 & 71 & 61 & 51 & 20 & 5.9 & 9.3 \\
\hline Apr & $\mathrm{S}$ & 10.9 & 46.8 & 94 & 76 & 67 & 58 & 33 & 4.2 & 7.5 \\
\hline May & $\mathrm{S}$ & 11.3 & 54.0 & 102 & 83 & 74 & 66 & 43 & 3.4 & 5.4 \\
\hline Jun & $\mathrm{S}$ & 10.9 & 66.0 & 103 & 88 & 80 & 72 & 54 & 5.6 & 6.3 \\
\hline Jul & $\mathrm{S}$ & 10.5 & 71.9 & 104 & 90 & 82 & 74 & 60 & 7.5 & 5.9 \\
\hline Aug & $\mathrm{S}$ & 10.1 & 51.9 & 102 & 90 & 81 & 74 & 61 & 6.7 & 6.8 \\
\hline Sep & $\mathrm{N}$ & 6.2 & 77.9 & 99 & 87 & 78 & 71 & 43 & 6.6 & 10.2 \\
\hline Oct & $\mathrm{N}$ & 6.4 & 99.8 & 94 & 80 & 70 & 61 & 33 & 3.7 & 6.9 \\
\hline Nov & $\mathrm{N}$ & 6.8 & 49.0 & 89 & 71 & 62 & 52 & 20 & 3.9 & 6.2 \\
\hline Dec & $\mathrm{N}$ & 7.0 & 55.9 & 80 & 64 & 55 & 44 & 9 & 4.5 & 7.7 \\
\hline Ann & $\mathrm{N}$ & 6.6 & 99.8 & 104 & 77 & 68 & 60 & 6 & 61.6 & 10.2 \\
\hline
\end{tabular}


Range Atmospheric and Oceanic Environmental Support Capabilities, RCC Document 354-11, December 2011

This page intentionally left blank. 


\section{CHAPTER 7}

\section{AIR FORCE FLIGHT TEST CENTER}

\subsection{Introduction}

NASA Dryden provides special services to the Air force Flight Test Center (AFFTC) customers. Edwards provides general coverage for Dryden, but Dryden provides field services where Edwards cannot. During local field campaigns, the Dryden weather group will provide upper air and surface measurements with balloons, surface observation systems, and sodars to meet the projects data requirements. Dryden also provides planning and climatology summaries when applicable.

\subsection{Weather Instrumentation}

a. Weather Radar: Doppler

(1) Purpose: daily range operations and missions.

(2) Uses: precipitation location and intensity, thunderstorm location, intensity, and rainfall and flash flood warning.

b. Satellite: GOES-11, GOES-12.

Receive Feed from Other Source List: satellite feed from NOAAPort.

c. Upper Air: radiosondes, rocketsondes, satellite derived soundings, sonic profiler, radar profiler, LIDAR profiler.

Specifics: Vaisala Digicora Portable Radiosonde System, Atmospheric Systems

Corp. SODAR 2000, Atmospheric Systems Corp. SODAR 4000.

d. Surface:

(1) AWOS/ASOS:

a) Rain gauge.

b) Anemometer: 2-Metek sonic anemometers.

c) Ceilometer.

(2) Other: five portable weather stations, equipment included: temperature, pressure, relative humidity, anemometer, and data loggers.

e. Lightning: web based products.

f. Other Instruments used in support of weather related efforts: FMQ-19, wind towers, radar, and semi-routine radiosonde launches.

g. Specialized NWP models: The majority of our data comes from the Edwards range or from on-line sources. 


\begin{tabular}{|c|c|c|c|c|c|c|c|c|c|c|}
\hline \multicolumn{11}{|c|}{ TABLE 7-1. AIR FORCE FLIGHT TEST CENTER CLIMATOLOGY } \\
\hline \multirow{3}{*}{ Month } & \multirow{2}{*}{\multicolumn{3}{|c|}{$\begin{array}{c}\text { Winds (knots) } \\
\text { Prevailing } \\
\end{array}$}} & \multicolumn{5}{|c|}{ Temperature $\left({ }^{\circ} \mathrm{F}\right)$} & \multicolumn{2}{|c|}{ Precip (inches) } \\
\hline & & & & \multirow{2}{*}{$\begin{array}{l}\text { Abs } \\
\text { Max } \\
\end{array}$} & \multirow{2}{*}{$\begin{array}{l}\text { Avg } \\
\text { Max }\end{array}$} & \multirow{2}{*}{ Avg } & \multirow{2}{*}{$\begin{array}{l}\text { Avg } \\
\text { Min }\end{array}$} & \multirow{2}{*}{$\begin{array}{l}\text { Abs } \\
\text { Min } \\
\end{array}$} & \multirow{2}{*}{ Mon } & \multirow{2}{*}{$\begin{array}{c}24 \mathrm{hr} \\
\text { Max }\end{array}$} \\
\hline & Dir & Spd & Peak & & & & & & & \\
\hline Jan & SW & 9.7 & 52.1 & 83 & 60 & 45 & 32 & 4 & 1.0 & 2.7 \\
\hline Feb & WSW & 12.0 & 55.0 & 82 & 62 & 48 & 36 & 14 & 1.0 & 2.5 \\
\hline Mar & SW & 10.9 & 52.1 & 90 & 70 & 55 & 41 & 19 & 0.8 & 3.4 \\
\hline Apr & WSW & 13.4 & 52.1 & 100 & 75 & 60 & 46 & 27 & 0.3 & 1.2 \\
\hline May & SW & 11.8 & 49.0 & 106 & 86 & 71 & 55 & 32 & 0.1 & 0.6 \\
\hline Jun & SW & 12.4 & 44.9 & 112 & 94 & 80 & 62 & 41 & 0.0 & 0.4 \\
\hline Jul & SW & 11.5 & 50.9 & 113 & 101 & 86 & 69 & 47 & 0.1 & 1.1 \\
\hline Aug & SW & 10.7 & 48.0 & 112 & 99 & 84 & 66 & 47 & 0.1 & 0.9 \\
\hline Sep & WSW & 11.8 & 40.0 & 109 & 92 & 76 & 58 & 37 & 0.2 & 1.3 \\
\hline Oct & SW & 9.9 & 59.1 & 100 & 81 & 64 & 48 & 20 & 0.3 & 1.3 \\
\hline Nov & SW & 8.9 & 44.9 & 86 & 68 & 53 & 39 & 13 & 0.5 & 1.5 \\
\hline Dec & SW & 9.7 & 50.9 & 84 & 58 & 44 & 32 & 4 & 0.7 & 1.6 \\
\hline Ann & SW & 11.1 & 59.1 & 113 & 79 & 64 & 49 & 4 & 5.2 & 3.4 \\
\hline
\end{tabular}




\section{CHAPTER 8}

\section{ELECTRONIC PROVING GROUND}

\subsection{Introduction}

The mission of the Electronic Proving Ground (EPG) Meteorological (MET) team is to collect, archive, and analyze weather information to support military and civilian test operations. The team provides climatology, daily forecasts, radar weather, watch/advisory/warning notifications, and upper air data for EPG planners, testers, and post operations. These services consist of test planning, test support (forecasting, meteorological measurements, and atmospheric characterization), test analysis, and test data reports. The team provides weather watches and warnings for high winds, heavy rainfall, severe thunderstorms, lightning, heat stress, wind chill, hail, and snow.

\subsection{Weather Instrumentation}

a. Upper Air: radiosondes.

b. Surface: anemometer.

c. Other: Surface Automated Meteorological System (SAMS) with atmospheric pressure, dew point, relative humidity, precipitation, and solar radiation.

d. Lightning Detection: sensor network.

e. Specialized NWP model: 4DWx from NCAR.

\begin{tabular}{|c|c|c|c|c|c|c|c|c|c|c|}
\hline \multirow{3}{*}{ Month } & \multirow{2}{*}{\multicolumn{3}{|c|}{$\begin{array}{c}\text { Winds (knots) } \\
\text { Prevailing }\end{array}$}} & \multicolumn{5}{|c|}{ "Temperature ( $\left.{ }^{\circ} \mathbf{F}\right)$} & \multicolumn{2}{|c|}{ Precip (inches) } \\
\hline & & & & \multirow{2}{*}{$\begin{array}{l}\text { Abs } \\
\text { Max } \\
\end{array}$} & \multirow{2}{*}{$\begin{array}{l}\text { Avg } \\
\text { Max }\end{array}$} & \multirow{2}{*}{ Avg } & \multirow{2}{*}{ Avg } & \multirow{2}{*}{$\begin{array}{l}\text { Abs } \\
\text { Min } \\
\end{array}$} & \multirow{2}{*}{$\begin{array}{c}\text { Mon } \\
\text { Avg } \\
\end{array}$} & \multirow{2}{*}{$24 \mathrm{hr}$} \\
\hline & Dir & Spd & Peak & & & & & & & \\
\hline 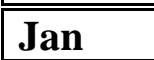 & $\overline{\mathrm{WW}}$ & 111.3 & 55.0 & 78 & 61 & 51 & 40 & 9 & 1.0 & 1.8 \\
\hline Feb & $\mathrm{W}$ & 11.8 & 49.0 & 82 & 64 & 53 & 42 & 3 & 0.7 & 1.4 \\
\hline Mar & $\mathrm{W}$ & 12.6 & 56.9 & 90 & 70 & 59 & 47 & 21 & 0.6 & 1.0 \\
\hline Apr & $\mathrm{W}$ & 12.0 & 50.9 & 95 & 77 & 66 & 54 & 24 & 0.3 & 1.1 \\
\hline May & $\mathrm{W}$ & 11.8 & 53.0 & 100 & 86 & 75 & 63 & 35 & 0.2 & 0.6 \\
\hline Jun & $\mathrm{W}$ & 10.5 & 54.0 & 104 & 93 & 82 & 71 & 49 & 0.5 & 1.2 \\
\hline Jul & $\mathrm{W}$ & 9.9 & 71.9 & 107 & 91 & 80 & 71 & 58 & 3.6 & 2.3 \\
\hline Aug & $\mathrm{W}$ & 8.7 & 49.9 & 101 & 88 & 78 & 69 & 55 & 3.8 & 2.5 \\
\hline Sep & $\mathrm{W}$ & 8.7 & 57.9 & 100 & 87 & 76 & 66 & 44 & 1.8 & 2.9 \\
\hline Oct & SW & 8.4 & 52.1 & 94 & 79 & 68 & 57 & 30 & 1.0 & 2.7 \\
\hline Nov & $\mathrm{W}$ & 9.7 & 45.1 & 86 & 69 & 59 & 47 & 18 & 0.6 & 2.4 \\
\hline Dec & $\mathrm{W}$ & 10.7 & 62.0 & 79 & 61 & 50 & 39 & 8 & 1.0 & 1.6 \\
\hline Ann & $\mathrm{W}$ & 10.9 & 71.9 & 107 & 77 & 67 & 56 & 3 & 15.2 & 2.9 \\
\hline
\end{tabular}


Range Atmospheric and Oceanic Environmental Support Capabilities, RCC Document 354-11, December 2011

This page intentionally left blank. 


\section{CHAPTER 9}

\section{NASA DRYDEN}

\subsection{Introduction}

NASA's Dryden Flight Research Center, located on Edwards Air Force Base (AFB), CA, provides special services to customers. Edwards AFB provides general coverage for Dryden, but Dryden provides field services where Edwards AFB cannot. During field campaigns, Dryden will provide upper air and surface measurements with balloons, surface observation systems, and sodars to meet the projects data requirements. Dryden also provides planning and climatology summaries when applicable.

\subsection{Weather Instrumentation}

a. Weather Radar: web based or products from Edwards direct feeds.

(1) Purpose: missions.

(2) Uses: precipitation location and intensity, thunderstorm location and intensity, and rainfall and flash flood warning.

b. Satellite: web based or products from Edwards direct feeds.

c. Upper Air: radiosondes, rocketsondes, satellite derived soundings, sonic profiler, radar profiler, LIDAR profiler.

Specifics: Vaisala Digicora Portable Radiosonde System, Atmospheric Systems

Corp. SODAR 2000, Atmospheric Systems Corp. SODAR 4000.

d. Surface: AWOS/ASOS - Edwards provided systems.

e. Lightning Detection: web based products.

f. Other instruments used in support of weather related efforts: none.

g. Specialized NWP model: the majority of our data comes from the Edwards range or from on-line sources.

\subsection{Climatology}

The climatology information is the same as AFFTC, Edwards AFB with the table located in Chapter 7 of this document. 
Range Atmospheric and Oceanic Environmental Support Capabilities, RCC Document 354-11, December 2011

This page intentionally left blank. 


\subsection{Introduction}

\section{CHAPTER 10}

\section{NASA KENNEDY SPACE CENTER}

The John F. Kennedy Space Center (KSC) is the NASA installation that has been the launch site for every US human space flight since 1968, and it is located on Merritt Island, FL. All of KSC's operational weather support is provided by $45^{\text {th }}$ Weather Squadron (45WS). Applied Meteorology Unit provides technology transition, evaluation, and development support to 45WS and JSC Spaceflight Meteorology Group in response to their tasking.

\subsection{Weather Instrumentation}

Upper Air: Radar Profiler - Specifics: $50 \mathrm{MHz}$ Doppler radar wind profiler located at the shuttle landing facility which produces wind profile from $\sim 3 \mathrm{~km}$ to $18 \mathrm{~km}$ every 10 minutes.

\subsection{Climatology}

The climatology information is the same as the $45^{\text {th }}$ Space Wing, Patrick AFB, FL with the table located in Chapter 4 of this document. 
Range Atmospheric and Oceanic Environmental Support Capabilities, RCC Document 354-11, December 2011

This page intentionally left blank. 


\section{CHAPTER 11}

\section{NAVAL AIR WARFARE CENTER WEAPONS DIVISION, ATLANTIC TEST RANGE}

\subsection{Introduction}

Located at Patuxent River, MD, the Atlantic Test Range (ATR) Weather (WX) provides flight weather briefs for all testing aircraft, 36-hour range outlook, and mission specific (dry versus wet aircraft) forecasts. This weather group also provides met data to Joint Strike Fighter (JSF) and unmanned aircraft system (UAS) testing missions within the ATR. The weather center will be gaining forecast and research program responsibilities in next 4-6 weeks.

\subsection{Weather Instrumentation}

a. Weather Radar Type: no weather radar. Weather Tap internet subscription.

(1) Purpose: daily range operations and missions.

(2) Uses: precipitation location/intensity and thunderstorm location/intensity.

b. Satellite: receive from Weather Tap, NWS, 15 Operational Weather Squadron (OWS), Joint Air Force Army Weather Information Network (JAAWIN) internet services.

c. Upper Air: none.

d. Surface:

(1) AWOS/ASOS: ceilometer, winds, temperature, relative humidity, pressure, visibility, prevailing weather, and rain gauge.

(2) Manual Surface Observations List Equipment: Kestrel for backup.

e. Lightning Detection: internet via JAAWIN, and Weather Tap.

f. Specialized NWP model: Fleet Numerical Meteorological Oceanography Center (FNMOC) Coupled Ocean Atmosphere Mesoscale Prediction System Operating Software (COAMPSOS) Atlantic Test Range General Plot Matrix 00Z and 12Z. $54 \mathrm{~K}, 18 \mathrm{~K}, 6 \mathrm{~K}$ and $2 \mathrm{~K}$ resolution. 


\begin{tabular}{|c|c|c|c|c|c|c|c|c|c|c|}
\hline \multicolumn{11}{|c|}{$\begin{array}{l}\text { TABLE 11-1. NAVAL AIR WARFARE CENTER WEAPONS DIVISION } \\
\text { ATLANTIC TEST RANGE CLIMATOLOGY }\end{array}$} \\
\hline \multirow{3}{*}{ Month } & \multirow{2}{*}{\multicolumn{3}{|c|}{\begin{tabular}{c|} 
Winds (knots) \\
Prevailing \\
\end{tabular}}} & \multicolumn{5}{|c|}{ "Temperature $\left({ }^{\circ} \mathrm{F}\right)$} & \multicolumn{2}{|c|}{ Precip (inches) } \\
\hline & & & & \multirow{2}{*}{ Abs } & \multirow{2}{*}{ Avg } & \multirow{2}{*}{ Avg } & \multirow{2}{*}{ Avg } & \multirow{2}{*}{$\begin{array}{l}\text { Abs } \\
\text { Min }\end{array}$} & \multirow{2}{*}{ Mon } & \multirow{2}{*}{24 hr } \\
\hline & Dir & Spd & Peak & & & & & & & \\
\hline Jan & $\begin{array}{ll}\mathrm{N} \\
\end{array}$ & 10.5 & 52.1 & 81 & 46 & 38 & 31 & -3 & 3.2 & 6.0 \\
\hline Feb & $\mathrm{N}$ & 10.1 & 46.0 & 80 & 47 & 38 & 31 & 5 & 3.0 & 3.1 \\
\hline Mar & $\mathrm{N}$ & 10.9 & 49.9 & 88 & 55 & 46 & 38 & 10 & 3.5 & 3.6 \\
\hline Apr & $\mathrm{N}$ & 9.9 & 46.8 & 92 & 65 & 55 & 47 & 26 & 3.2 & 3.1 \\
\hline May & SSE & 7.8 & 46.0 & 98 & 73 & 65 & 57 & 36 & 3.5 & 5.3 \\
\hline Jun & SW & 7.0 & 55.9 & 101 & 82 & 74 & 66 & 45 & 3.4 & 5.9 \\
\hline Jul & $\mathrm{S}$ & 6.2 & 53.0 & 103 & 85 & 78 & 70 & 55 & 4.4 & 4.6 \\
\hline Aug & $\mathrm{S}$ & 6.4 & 55.0 & 103 & 85 & 77 & 71 & 53 & 4.1 & 5.9 \\
\hline Sep & $\mathrm{N}$ & 9.3 & 60.0 & 99 & 78 & 70 & 64 & 45 & 3.3 & 4.3 \\
\hline Oct & $\mathrm{N}$ & 9.7 & 52.8 & 92 & 68 & 60 & 51 & 30 & 2.9 & 3.6 \\
\hline Nov & $\mathrm{N}$ & 11.1 & 58.9 & 84 & 59 & 51 & 43 & 16 & 2.7 & 4.2 \\
\hline Dec & $\mathrm{N}$ & 9.5 & 46.0 & 81 & 49 & 42 & 34 & 6 & 0.0 & 3.6 \\
\hline Ann & $\mathrm{N}$ & 9.7 & 60.0 & 103 & 66 & 58 & 50 & 2.9 & 40.1 & 6.0 \\
\hline
\end{tabular}




\section{CHAPTER 12}

\section{NAVAL AIR WARFARE CENTER WEAPONS DIVISION, CHINA LAKE}

\subsection{Introduction}

Naval Air Warfare Center Weapons Division (NAWC-WD), China Lake weather office provides upper air radiosonde support when requested along with surface weather stations. NAWC-WD China Lake has eight permanent weather stations located around the range to provide continuous weather conditions along with climatological information for upcoming events. Detailed range forecasts are provided for NAWC-WD China Lake range operations. Special operations include tethersonde operations, 50-foot wind poles, soil temperature information, solar radiate on, BLAST Refocus Noise Assessment, and slant range visibility observations for laser tests.

\subsection{Weather Instrumentation}

a. Weather Radar: Doppler

(1) Specifics: Internet only with feed from Edwards Boron CA radar.

(2) Purpose: daily range operations and missions.

(3) Uses: precipitation location and intensity, thunderstorm location and intensity, and rainfall or flash flood warning.

b. Satellite: NOAA-15, NOAA-16, GOES-10, GOES-11, GOES-12, NOAA-17, NOAA-18, and NOAA-19. (Internet only).

c. Upper Air: radiosondes.

d. Surface:

(1) Rain Gauge: 6-inch plastic range gauge.

(2) Manual Surface Observations List Equipment: GMQ9 hand held wind sensor, Rotronics temp/relative humidity sensor, AIR digital barometer.

(3) AWOS/ASOS: ceilometer, winds, temperature, relative humidity, pressure, visibility, prevailing weather, and rain gauge.

e. Lightning Detection: Field Mill and TSS 928.

f. Any other instruments used in support of weather related efforts:

(1) HANDAR 555 weather stations.

(2) Davis Instruments weather stations.

(3) MAWS 120 weather stations.

g. Specialized NWP model: none. 
TABLE 12-1. NAVAL AIR WARFARE CENTER WEAPONS DIVISION, CHINA LAKE CLIMATOLOGY

\begin{tabular}{|c|c|c|c|c|c|c|c|c|c|c|}
\hline \multirow{3}{*}{ Month } & \multirow{2}{*}{\multicolumn{3}{|c|}{$\begin{array}{c}\text { Winds (knots) } \\
\text { Prevailing } \\
\end{array}$}} & \multicolumn{5}{|c|}{ Temperature $\left({ }^{\circ} \mathrm{F}\right)$} & \multicolumn{2}{|c|}{ Precip (inches) } \\
\hline & & & & \multirow{2}{*}{$\begin{array}{l}\text { Abs } \\
\text { Max } \\
\end{array}$} & \multirow{2}{*}{$\frac{\text { Avg }}{\text { Max }}$} & \multirow{2}{*}{ Avg } & \multirow{2}{*}{$\begin{array}{l}\text { Avg } \\
\text { Min }\end{array}$} & \multirow{2}{*}{$\frac{\text { Abs }}{\text { Min }}$} & \multirow{2}{*}{$\frac{\text { Mon }}{\text { Avg }}$} & \multirow{2}{*}{$\begin{array}{l}24 \mathrm{hr} \\
\text { Max }\end{array}$} \\
\hline & Dir & Spd & Peak & & & & & & & \\
\hline Jan & 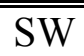 & 07 & 67 & 80 & 59 & 44 & 30 & 0.90 & 0.95 & 0.90 \\
\hline Feb & SW & 09 & 69 & 89 & 64 & 50 & 35 & 0.90 & 0.93 & 0.90 \\
\hline Mar & SW & 10 & 70 & 92 & 70 & 55 & 41 & 2.20 & 0.76 & 2.20 \\
\hline Apr & SW & 11 & 64 & 104 & 79 & 63 & 48 & 0.90 & 0.10 & 0.90 \\
\hline May & SW & 11 & 77 & 108 & 86 & 71 & 56 & 1.00 & 0.10 & 1.00 \\
\hline Jun & SW & 11 & 59 & 118 & 96 & 80 & 64 & 0.30 & 0.02 & 0.30 \\
\hline Jul & SW & 10 & 49 & 119 & 102 & 86 & 71 & 0.60 & 0.16 & 0.60 \\
\hline Aug & SW & 09 & 46 & 119 & 100 & 84 & 68 & 1.60 & 0.31 & 1.60 \\
\hline Sep & SW & 09 & 60 & 114 & 94 & 78 & 61 & 1.53 & 0.20 & 1.53 \\
\hline Oct & SW & 09 & 60 & 103 & 82 & 66 & 50 & 0.80 & 0.14 & 0.80 \\
\hline Nov & SW & 08 & 62 & 90 & 68 & 53 & 38 & 1.00 & 0.34 & 1.00 \\
\hline Dec & SW & 07 & 76 & 77 & 59 & 45 & 30 & 0.90 & 0.52 & 0.90 \\
\hline Ann & SW & 09 & 77 & 119 & 80 & 65 & 50 & 2.20 & 4.53 & 2.20 \\
\hline
\end{tabular}




\section{CHAPTER 13}

\section{NAVAL AIR WARFARE CENTER WEAPONS DIVISION, POINT MUGU}

\subsection{Introduction}

Naval Air Warfare Center Weapons Division, Point Mugu weather center provides upper air radiosonde measurements when requested, along with surface weather stations. The Sea Range has five permanent weather stations and five temporary weather stations located around the range areas to provide continuous weather conditions along with climatological information for upcoming events. Detailed range forecasts are provided for local Range project test operations. Special operations include tethersonde operations, wind poles, lightning and static information, solar radiation, BLAST Refocus Noise Assessment, sonic boom predictions, boatlaunched radiosondes, two-dimensional helicopter atmospheric measurements, climatology products, and GIS-based scenario propagation analyses.

\subsection{Weather Instrumentation}

a. Weather Radar Type: Doppler.

(1) Specifics: internet only, does not have an actual feed.

(2) Purpose: daily range operations, missions, and airfield operations at Point Mugu and San Nicolas Island.

(3) Uses: precipitation location and intensity, thunderstorm location and intensity, rainfall and flash flood warning, wind warnings and tornados.

b. Satellite:

(1) NOAA-15, NOAA-16, DMSP F13, DMSP F14, DMSP F16, GOES-10, GOES-11, GOES-12, NOAA-18, NOAA-19, Chinese FengYun, Russian METEOR, GOES-LRIT, DMSP F17, and in the future DMSP F18.

(2) Direct Feed List: SMQ-11 tactical system, maintained by SPAWAR.

c. Upper Air:

(1) Radiosondes, sonic wind profiler and radar profiler at Point Mugu and San Nicolas Island.

(2) Other: Tethersonde and 100-foot wind pole.

d. Surface:

(1) Ceilometer: AllWeatherInc Model 8339 on San Nicolas Island.

(2) Rain gauge: 6-inch plastic range gauge.

(3) Anemometer: Handar 555, Davis VantagePro, Weatherflow-Vendor Lease, and NOAA (assoc. with 449 Profiler).

(4) Manual Surface Observations Equipment: Kestrel 4000 handheld wind sensor, Handheld Solar Pyranometer, and wind socks.

(5) AWOS/ASOS equipment: Ceilometer, winds, temperature, relative humidity, pressure, visibility, prevailing weather (Point Mugu and San Nicolas Island).

e. Lightning Detection:

(1) NLDN data (JAAWIN web site, and IPS/Meteostar Subscriber Service Accounts at the LR and SR.

(2) Field Mill (Mainland Mugu and San Nicolas Island). 
f. Any other instruments used in support of weather related efforts:

(1) Datawell Waverider Buoys: Moored 1 meter and portable $20 \mathrm{~cm}$, for 9-band sea swell and direction, and sea surface temperatures.

(2) Particle Number Concentration Sensors.

(3) Aerosol Mass Concentration Sensors.

g. Specialized NWP models:

(1) COAMPS atmospheric model for 56 parameters, self-operated on a rented Linux cluster, hosted by SCCOOS. Operated four times daily and forecasting for up to 84 hours.

(2) $54 \mathrm{~km}, 18 \mathrm{~km}$, and $6 \mathrm{~km}$ nested grids covering the western U.S. region from $\sim 1200$ nautical miles (NM) west of Seattle to 200 NM east of Brownsville.

h. Specialized NWP model: none.

\begin{tabular}{|c|c|c|c|c|c|c|c|c|c|c|}
\hline \multirow{4}{*}{ Month } & \multicolumn{10}{|c|}{$\begin{array}{l}\text { TABLE 13-1. NAVAL AIR WARFARE CENTER WEAPONS DIVISION } \\
\text { POINT MUGU }\end{array}$} \\
\hline & \multirow{2}{*}{\multicolumn{3}{|c|}{$\begin{array}{c}\text { Winds (knots) } \\
\text { Prevailing }\end{array}$}} & \multicolumn{5}{|c|}{ Temperature $\left({ }^{\circ} \mathbf{F}\right)$} & \multicolumn{2}{|c|}{ "Precip (inches) } \\
\hline & & & & \multirow{2}{*}{ Abs } & \multirow{2}{*}{ Avg } & \multirow{2}{*}{ Avg } & \multirow{2}{*}{ Mvg } & \multirow{2}{*}{$\begin{array}{l}\text { Abs } \\
\text { Min }\end{array}$} & \multirow{2}{*}{ Mon } & \multirow{2}{*}{ Max } \\
\hline & Dir & Spd & Peak & & & & & & & \\
\hline Jan & $\mathrm{N} \mathrm{N}$ & 5.1 & 48.0 & 90 & 64 & 54 & 46 & 31 & 3.6 & 2.8 \\
\hline Feb & $\mathrm{W}$ & 9.9 & 44.9 & 88 & 63 & 55 & 46 & 32 & 3.2 & 4.8 \\
\hline Mar & $\mathrm{W}$ & 9.9 & 44.9 & 97 & 63 & 56 & 47 & 34 & 2.6 & 2.9 \\
\hline Apr & $\mathrm{W}$ & 10.5 & 43.9 & 100 & 64 & 56 & 48 & 34 & 0.9 & 1.0 \\
\hline May & $\mathrm{W}$ & 8.7 & 41.0 & 95 & 66 & 59 & 52 & 34 & 0.3 & 0.6 \\
\hline Jun & $\bar{W}$ & 8.4 & 39.0 & 100 & 69 & 62 & 55 & 41 & 0.1 & 0.3 \\
\hline Jul & $\mathrm{W}$ & 8.2 & 29.9 & 92 & 72 & 65 & 58 & 44 & 0.0 & 0.2 \\
\hline Aug & $\mathrm{W}$ & 8.2 & 34.0 & 88 & 72 & 65 & 58 & 46 & 0.0 & 1.0 \\
\hline Sep & $\mathrm{W}$ & 8.0 & 66.0 & 100 & 72 & 64 & 57 & 46 & 0.1 & 2.4 \\
\hline Oct & $\mathrm{W}$ & 7.8 & 49.0 & 104 & 70 & 62 & 54 & 39 & 0.5 & 1.0 \\
\hline Nov & $\mathrm{N}$ & 4.9 & 46.0 & 97 & 67 & 58 & 50 & 34 & 1.4 & 2.1 \\
\hline Dec & $\mathrm{N}$ & 5.1 & 48.0 & 87 & 64 & 54 & 46 & 29 & 2.6 & 1.5 \\
\hline Ann & W & 8.7 & 66.0 & 104 & 67 & 59 & 52 & 29 & 15.2 & 0.0 \\
\hline
\end{tabular}




\section{CHAPTER 14}

\subsection{Introduction}

\section{PACIFIC MISSILE RANGE FACILITY}

Pacific Missile Range Facility (PMRF) Meteorological Operations Center (MOC) supports a broad array of missions and provides a great deal of products to customers. Aviation, maritime, marine, surf, tropical, and microscale forecasts are just some products provided during missions and special operations, as well as providing a daily forecast with marine conditions via our website. The MOC coordinates closely with U.S. military and government agencies during operations to ensure consistency and provides briefings to military and civilian commanders during test and evaluation missions.

\subsection{Weather Instrumentation}

a. Satellite: internet derived actual feed.

b. Upper Air: radiosondes, and rocketsondes.

c. Surface:

1. Ceilometer, rain gauge, and anemometer.

2. AWOS/ASOS: ceilometer, winds, temperature, relative humidity, pressure, visibility, prevailing weather, and rain gauge.

d. Specialized NWP model: none.

\begin{tabular}{|c|c|c|c|c|c|c|c|c|c|c|}
\hline \multirow{4}{*}{ Month } & \multicolumn{10}{|c|}{ TABLE 14-1. PACIFIC MISSILE RANGE FACILITY } \\
\hline & \multirow{2}{*}{\multicolumn{3}{|c|}{$\begin{array}{c}\text { Winds (knots) } \\
\text { Prevailing }\end{array}$}} & \multicolumn{5}{|c|}{ "Temperature $\left({ }^{\circ} \mathbf{F}\right)$} & \multicolumn{2}{|c|}{ Precip (inches) } \\
\hline & & & & \multirow{2}{*}{$\begin{array}{c}\text { Abs } \\
\text { Max } \\
\end{array}$} & \multirow{2}{*}{$\begin{array}{l}\text { Avg } \\
\text { Max } \\
\end{array}$} & \multirow{2}{*}{ Avg } & \multirow{2}{*}{ Avg } & \multirow{2}{*}{$\begin{array}{l}\text { Abs } \\
\text { Min } \\
\end{array}$} & \multirow{2}{*}{ Mon } & \multirow{2}{*}{$\begin{array}{c}24 \text { hr } \\
\text { Max }\end{array}$} \\
\hline & Dir & Spd & Peak & & & & & & & \\
\hline Jan & SE & 09 & 41 & 87 & 78 & 74 & 68 & 52 & 4.1 & 4.6 \\
\hline Feb & $\mathrm{N}$ & 12 & 37 & 88 & 78 & 74 & 68 & 50 & 2.3 & 5.3 \\
\hline Mar & $\mathrm{W}$ & 06 & 35 & 89 & 79 & 75 & 68 & 50 & 2.1 & 4.8 \\
\hline Apr & $\mathrm{W}$ & 06 & 35 & 91 & 80 & 77 & 70 & 56 & 1.2 & 3.9 \\
\hline May & $\mathrm{W}$ & 06 & 34 & 94 & 82 & 78 & 73 & 54 & 0.9 & 2.9 \\
\hline Jun & $\mathrm{W}$ & 06 & 26 & 94 & 83 & 80 & 75 & 59 & 0.3 & 1.1 \\
\hline Jul & $\mathrm{W}$ & 07 & 25 & 94 & 84 & 81 & 76 & 60 & 0.5 & 2.5 \\
\hline Aug & $\mathrm{W}$ & 06 & 59 & 95 & 85 & 82 & 76 & 62 & 0.7 & 4.9 \\
\hline Sep & $\mathrm{W}$ & 06 & 55 & 95 & 85 & 82 & 75 & 62 & 0.9 & 3.1 \\
\hline Oct & $\mathrm{W}$ & 06 & 40 & 92 & 84 & 81 & 74 & 59 & 2.2 & 5.7 \\
\hline Nov & $\mathrm{W}$ & 05 & 44 & 90 & 82 & 78 & 72 & 55 & 2.8 & 5.4 \\
\hline Dec & $\mathrm{N}$ & 10 & 45 & 89 & 80 & 76 & 70 & 48 & 3.9 & 6.0 \\
\hline Ann & $\mathrm{W}$ & 07 & 59 & 95 & 82 & 78 & 72 & 48 & 21.9 & 6.0 \\
\hline
\end{tabular}


Range Atmospheric and Oceanic Environmental Support Capabilities, RCC Document 354-11, December 2011

This page intentionally left blank. 


\section{CHAPTER 15}

\section{REAGAN TEST SITE}

\subsection{Introduction}

Reagan Test Site (RTS) offers a reliable, high-quality small business alternative to inhouse resources for government operated weather stations, instrumented sites, research support, consulting, technical and business management of government contracts.

Forecasts are produced by a staff of meteorologists in a state-of-the-art weather office on Kwajalein Island in the Republic of the Marshall Islands. The facility boasts an S-band dualpolarized Doppler weather radar, full weather satellite capabilities utilizing the Man-computer Interactive Data Access System (McIDAS) and CineSat (satellite) display and analysis systems, upper air and surface meteorological measurement systems, lightning detection equipment, and an atoll-wide system of automated surface observing stations (mesonet).

Reagan Test Site Weather provides specialized meteorological support to RTS during mission operations, as well as daily support to the general public, aviation and marine communities. This group also supports a variety of scientific research efforts. As a ground validation site for the Tropical Rainfall Measuring Mission (TRMM), RTS meteorologists collect dual-polarized Doppler weather radar data, rainfall measurements from rain gauges on seven islands within the atoll, and rainfall drop-size distribution information via disdrometers. The staff helps monitor global climate change by collecting data for National Oceanic and Atmospheric Administration's Global Monitoring Division and the Department of Energy's Atmospheric Radiation Measurement program.

Reagan Test Site provides services in support of range operations to include: weather watch (24 hours a day, seven days a week), public forecast, aviation forecast, marine forecast, mission forecast, airfield observations, SAR support, and emergency operations.

\subsection{Weather Instrumentation}

a. Weather Radar Type: Multi-Doppler, and dual-polarization.

(1) Purpose: daily range operations, and missions.

(2) Uses: precipitation location and intensity, thunderstorm location and intensity, lightning monitoring, rainfall and flash flood warning, hydrometer characterization, and wind warnings.

b. Satellite: MTSAT, GOES-10, GOES-11, GOES-12, COSMIC and METOP.

(1) Direct Feed: GOES, Polar Orbiting Environmental Satellite.

(2) Live feed.

c. Upper Air: radiosondes, rocketsondes, satellite derived soundings.

d. Surface:

(1) Ceilometer, rain gauge, and anemometer.

(2) AWOS/ASOS: temperature, pressure, dew point, rainfall, cloud height, wind speed and direction, visibility, present weather, and thunderstorm activity. 
e. Lightning detection: stand-alone sensor, sensor network, and field mill.

f. Other instruments used in support of weather related efforts: Mesonet providing wind, temperature, rainfall, pressure, and humidity every minute.

g. Specialized NWP model: none.

\begin{tabular}{|c|c|c|c|c|c|c|c|c|c|c|}
\hline & & T: I & $15-1$ & EAG & TES & ITE & IMA & 0 & & \\
\hline & & nds (k & & & Tem & ratur & $\left.{ }^{\circ} \mathbf{F}\right)$ & & $\bar{P}_{\text {Preci }}$ & inches) \\
\hline Month & & revail & & Abs & Avg & Aya & Avg & Abs & Mon & $24 \mathrm{hr}$ \\
\hline & Dir & Spd & Peak & Max & Max & Avg & Min & Min & Avg & Max \\
\hline Jan & ENE & 16.1 & 55.9 & 90 & 885 & 82 & 79 & 73 & 4.2 & 5.3 \\
\hline Feb & ENE & 15.5 & 42.0 & 93 & 85 & 82 & 79 & 73 & 3.0 & 4.3 \\
\hline Mar & ENE & 15.7 & 38.8 & 95 & 86 & 82 & 80 & 73 & 4.2 & 6.4 \\
\hline Apr & ENE & 15.0 & 35.0 & 95 & 86 & 83 & 80 & 72 & 6.8 & 5.2 \\
\hline May & ENE & 13.6 & 43.9 & 91 & 86 & 83 & 80 & 73 & 8.9 & 8.4 \\
\hline Jun & ENE & 12.8 & 42.0 & 90 & 86 & 83 & 80 & 72 & 9.0 & 8.8 \\
\hline Jul & ENE & 12.0 & 44.9 & 92 & 86 & 82 & 79 & 72 & 10.0 & 4.9 \\
\hline Aug & $\mathrm{E}$ & 10.1 & 43.9 & 93 & 87 & 83 & 79 & 73 & 10.5 & 5.4 \\
\hline Sep & ENE & 10.3 & 38.8 & 95 & 87 & 83 & 80 & 72 & 11.0 & 4.6 \\
\hline Oct & $\mathrm{E}$ & 10.5 & 44.9 & 93 & 86 & 82 & 79 & 72 & 12.0 & 6.1 \\
\hline Nov & ENE & 14.0 & 58.1 & 93 & 86 & 83 & 80 & 72 & 11.1 & 7.2 \\
\hline Dec & ENE & 15.5 & 53.0 & 92 & 86 & 82 & 80 & 73 & 8.0 & 11.2 \\
\hline Ann & ENE & 14.2 & 58.1 & 95 & 86 & 82 & 80 & 72 & 98.8 & 11.2 \\
\hline
\end{tabular}




\section{CHAPTER 16}

\section{WHITE SANDS MISSILE RANGE}

\subsection{Introduction}

White Sands Missile Range (WSMR) is located in south-central New Mexico. The WSMR Post Headquarters is about 50 miles north of El Paso, TX and 25 miles east of Las Cruces, NM. The main range occupies a land area approximately 40 miles (east-west) by 100 miles (north-south). In addition, a leased range extension, 40 square miles, lies adjacent to the northern boundary. The Range can be extended westward by activating several other smaller extensions on the western boundary of the Range.

The climatic and geographical environments of WSMR are particularly suitable for missile and rocket testing operations. Meteorological conditions typical of the desert provide excellent year-round visibility with good coverage by optical instrumentation obtainable about 95 percent of the time, both day and night. Almost all activities on WSMR require some meteorological support.

WSMR is a highly instrumented missile range. Over the vast expanse of land, the meteorological team collects weather data at both permanent and mobile sites. The following meteorological activities are available at WSMR:

a. Meteorological planning services, matching customer requirements and requests with capabilities. Quality-control of post-mission data reports. (Normal)

b. Climatological studies: custom test-planning information derived from a $20+$ year Surface Automated Measurement System (SAMS) and 15+ year radiosonde observation (ROAB) database archive. (Normal)

c. Sounding rocket impact prediction: Fully mobile system to integrate surface, boundary-layer, and upper-air wind data. Data is ingested by software developed in-house to provide wind-weighted solutions for impact points and/or launcher settings (azimuth/quadrant elevation). Tower display features an automatic red/green GO/NO-GO decision support tool. System has been successfully used for dozens of launches at WSMR, as well as off-Range locations such as San Nicolas Island, CA, Woomera Rocket Range, Australia, and Pacific Missile Range, HI. (Normal)

d. Mission-specific weather forecasting and advising, on various timescales from T-minus 7-10 days down to realtime. (Normal)

e. Lightning/Weather Watches: Real-time monitoring of mission-critical weather criteria and lightning strike information available via telephone or in-person at Range Control Center ensure safety of personnel in the field. (Normal)

f. Base warning services during Army RDT\&E activities and normal Garrison working hours: Warnings for high winds, thunderstorms, snow/ice, visibility, etc. (Normal)

g. Balloon- and chaff-drift predictions. (Occasional) 


\subsection{Weather Instrumentation}

a. Weather Radar Type: Doppler, Multi-Doppler.

(1) Specifics: Direct feed of Level II NEXRAD data (via NCAR) from HDX, EPZ, and ABX. These data are displayed and analyzed by the 4DWx Thunderstorm Autonowcaster (ANC). Also, Level III products from approximately 25 other sites of interest are ingested via NOAAPort and displayed with N-AWIPS software.

(2) Purpose: daily range operations, missions and the 4DWx ANC facilitates lightning meteorological watches by ingesting 3-D lightning data (described below) into a fuzzy-logic algorithm which forecasts thunderstorm initiation and development in the 0-60 minute timeframe. Data can be archived for "hind cast" studies.

(3) Uses: precipitation location and intensity, thunderstorm location and intensity, and rainfall or flash flood warnings.

(4) Additional Specifics: level II radial velocity data aid in identification of the relatively rare but still high-impact occurrences of severe thunderstorms.

b. Satellite: GOES-11 and GOES-12.

Direct Feed List: Visible (1-km resolution), IR (4-km) and water vapor channels via NOAAPort; displayed with N-AWIPS.

c. Upper Air: radiosondes, sonic profiler and radar profiler.

Specifics: Hundreds of radiosondes launched yearly from sites throughout WSMR; data delivered in standard NASA formats and NATO ballistic met message. One sodar is available. NWS 404-MHz wind profiler located on southern WSMR. Four mobile 915-MHz profilers. Two wind-finding tracking radars (WF-100).

d. Surface:

(1) Ceilometer: 2 Vaisala CL-31.

(2) Rain Gauge: tipping-bucket; co-located with SAMS sites.

(3) Anemometer: R. M. Young Models 5103 and/or 5305, depending on location.

(4) AWOS/ASOS List Equipment: Ceilometer, winds, temp, relative humidity, pressure, visibility, prevailing weather, and rain gauge.

(5) Other: eight 20-m mobile wind towers. Three 34-m mobile wind towers. SAMS mesonet of approximately 20 stations, spread across WSMR. Each measures 10-m wind speed/direction, temperature, relative humidity, pressure, solar radiation, and precipitation at 1-15 minute intervals; also can be equipped with carbon dioxide sensor.

e. Lightning Detection:

(1) NLDN Data: direct satellite feed from Vaisala.

(2) Stand-alone Sensor: Mobile StrikeGuard flash-detection systems.

(3) Sensor Network: research-grade 3-D Lightning Mapping Array (3D-LMA) covers entire Range.

(4) Other: WeatherBug lightning network data ingested into 4DWx database; can also be displayed real-time with IDV software.

(5) Specifics: 3D-LMA designed, built, and maintained with assistance from experts at New Mexico Tech. 
f. Any other instruments used in support of weather related efforts:

(1) Tethered-balloon system measures wind speed/direction, temperature, relative humidity, and pressure at up to six user-selectable altitudes in the boundary layer (up to $1200 \mathrm{~m}$ AGL).

(2) Wet bulb globe temperature apparatus measures heat stress index in accordance with Army safety regulations.

g. Specialized NWP models: WRF ver. 3.1, locally run by NCAR through the 4DWx system. WRF utilizes Four-Dimensional Data Assimilation (RT-FDDA) strategies by ingesting all manner of Range data (e.g., surface, upper-air) to nudge model output toward observations. The WRF/RT-FDDA is run on 3 nested grids, with grid-point spacing progressively decreasing from $30 \mathrm{~km}$ down to $1.1 \mathrm{~km}$ on the innermost grid. Customized WRF configurations are also run periodically in support of off-range testing with the 4DWx Global Meteorology On-Demand tool.

\begin{tabular}{|c|c|c|c|c|c|c|c|c|c|c|}
\hline & TAI & $16-$ & WH & $\mathbf{A N}$ & MIS & $\mathbf{R}$ & E C & MA & LOGY & \\
\hline \multirow{3}{*}{ Month } & \multirow{2}{*}{\multicolumn{3}{|c|}{$\begin{array}{c}\text { Winds (knots) } \\
\text { Prevailing }\end{array}$}} & \multicolumn{5}{|c|}{ Temperature $\left({ }^{\circ} \mathbf{F}\right)$} & \multicolumn{2}{|c|}{ "Precip (inches) } \\
\hline & & & & \multirow{2}{*}{$\frac{\text { Abs }}{\text { Max }}$} & \multirow{2}{*}{$\frac{\text { Avg }}{\text { Max }}$} & \multirow{2}{*}{ Avg } & \multirow{2}{*}{ Avg } & \multirow{2}{*}{$\begin{array}{l}\text { Abs } \\
\text { Min }\end{array}$} & \multirow{2}{*}{$\frac{\text { Mon }}{\text { Avg }}$} & \multirow{2}{*}{$\frac{24 \mathrm{hr}}{\text { Max }}$} \\
\hline & Dir & Spd & Peak & & & & & & & \\
\hline בJan & "W & 8.9 & 35.9 & 74 & 57 & 46 & 36 & -5 & 0.64 & 1.37 \\
\hline Feb & $\mathrm{W}$ & 9.9 & 41.0 & 82 & 62 & 50 & 41 & 15 & 0.57 & 1.57 \\
\hline Mar & $\mathrm{W}$ & 12.0 & 42.9 & 83 & 67 & 56 & 46 & 23 & 0.40 & 1.04 \\
\hline Apr & $\mathrm{W}$ & 11.1 & 44.1 & 95 & 78 & 66 & 55 & 33 & 0.29 & 0.97 \\
\hline May & $\mathrm{W}$ & 11.1 & 35.9 & 104 & 85 & 74 & 62 & 40 & 0.38 & 1.50 \\
\hline Jun & $\mathrm{W}$ & 8.9 & 28.0 & 107 & 94 & 83 & 72 & 55 & 0.85 & 2.40 \\
\hline Jul & $\mathrm{SE}$ & 7.0 & 29.9 & 107 & 94 & 83 & 73 & 59 & 2.17 & 2.31 \\
\hline Aug & $\mathrm{W}$ & 6.0 & 26.0 & 102 & 93 & 82 & 71 & 58 & 2.00 & 3.60 \\
\hline Sep & $\mathrm{W}$ & 7.0 & 29.9 & 103 & 89 & 77 & 66 & 42 & 1.58 & 3.49 \\
\hline Oct & $\mathrm{W}$ & 7.0 & 32.1 & 91 & 78 & 66 & 56 & 35 & 1.11 & 1.95 \\
\hline Nov & $\mathrm{W}$ & 8.9 & 35.9 & 85 & 64 & 52 & 43 & 21 & 0.57 & 0.99 \\
\hline Dec & $\mathrm{W}$ & 8.9 & 44.1 & 78 & 57 & 46 & 37 & 9 & 0.85 & 1.65 \\
\hline Ann & $\mathrm{W}$ & 8.1 & 44.1 & 107 & 94 & 65 & 55 & -5 & 11.41 & 3.60 \\
\hline
\end{tabular}


Range Atmospheric and Oceanic Environmental Support Capabilities, RCC Document 354-11, December 2011

This page intentionally left blank. 


\section{CHAPTER 17}

\section{WRIGHT-PATTERSON AFB}

\subsection{Introduction}

Staff meteorological support from Wright-Patterson AFB (Detachment 3 of Air Force Weather Agency) aids in the preservation and enhancement of the Air Force's warfighting superiority. Staff meteorologists support a variety of activities in the Air Force Research Laboratory and Aeronautical Systems Centers ensuring that environmental considerations are included from inception of a project throughout its lifetime. Services include, but are not limited to, climatological data for engineering design, mission planning services to include climatological data for site or time of mission selection, sensor selection/data collection planning, go/no-go meteorological criteria selection, mission support (forecast and/or countdown as required), and post-mission data analysis. Staff meteorologists also perform environmental sensitivity studies and mishap investigations as requested by various programs.

While not an operational range, staff meteorologists support testing at many ranges across the nation including White Sands Missile Range, Yuma Proving Ground, Vandenberg AFB, Pacific Missile Range Facility, and Reagan Test Site. Support is also provided locally to the Air Force Research Lab Sensors Directorate Wright Field test area. International support has been provided to Woomera Test Range in southern Australia.

\subsection{Instrumentation}

a. Weather Radar Type: Internet sources-NWS, FAA output.

(1) Purpose: missions.

(2) Uses: precipitation location and intensity.

b. Satellite: MTSAT, DMSP F14, DMSP F16, COSMIC, GOES-11, NOAA-18, and CALIPSO.

(1) Other: GOES-13, GOES-15.

(2) Receive Feed from Other Source List: JAAWIN, Internet (NASA), NWS, NCAR.

c. Upper Air: although Wright-Patterson AFB has no equipment, the base utilizes radiosonde, met rocket, satellite derived soundings, and profiler (radar, LIDAR) data from other Ranges as needed. Observations are generally provided by other ranges for our analysis or through equipment owned by a particular program.

d. Surface: observations obtained from the ranges utilized or through program instrumentation. Wright-Patterson AFB does not maintain any surface observing equipment.

e. Lightning Detection: Wright-Patterson AFB utilizes lightning data from NLDN and what is listed as OCONUS Vaisala network (data obtained through JAAWIN). 
f. Specialized NWP models: none. Staff meteorologists utilize locally run atmospheric transmission models to include High Energy Laser End-to-End Operational Simulation and Laser Environmental Effects Definition and Reference obtained through Air Force Institute of Technology, and Phillips Laboratory Expert-assisted User Software which contains code for MODTRAN, SMM FASCODE, SHRARC and celestial backgrounds scene descriptor models - obtained through Air Force Research Laboratory.

TABLE 17-1. WRIGHT-PATTERSON AIR FORCE BASE CLIMATOLOGY

\begin{tabular}{|c|c|c|c|c|c|c|c|c|c|c|}
\hline \multirow{3}{*}{ Month } & \multirow{2}{*}{\multicolumn{3}{|c|}{$\begin{array}{c}\text { Winds (knots) } \\
\text { Prevailing } \\
\end{array}$}} & \multicolumn{5}{|c|}{ Temperature $\left({ }^{\circ} \mathbf{F}\right)$} & \multicolumn{2}{|c|}{ Precip (inches) } \\
\hline & & & & \multirow{2}{*}{$\begin{array}{l}\text { Abs } \\
\text { Max }\end{array}$} & \multirow{2}{*}{$\begin{array}{l}\text { Avg } \\
\text { Max }\end{array}$} & \multirow{2}{*}{ Avg } & \multirow{2}{*}{$\begin{array}{l}\text { Avg } \\
\text { Min }\end{array}$} & \multirow{2}{*}{$\begin{array}{l}\text { Abs } \\
\text { Min } \\
\end{array}$} & \multirow{2}{*}{$\frac{\text { Mon }}{\text { Avg }}$} & \multirow{2}{*}{$\frac{24 \mathrm{hr}}{\text { Max }}$} \\
\hline & Dir & Spd & Peak & & & & & & & \\
\hline Jan & W & 10.9 & 62.0 & 72 & 39 & 31 & 24 & -20 & 2.9 & 3.8 \\
\hline Feb & $\mathrm{W}$ & 10.7 & 59.1 & 75 & 42 & 32 & 25 & -11 & 2.3 & 2.6 \\
\hline Mar & $\mathrm{W}$ & 10.1 & 48.0 & 82 & 52 & 41 & 32 & -2 & 3.3 & 3.4 \\
\hline Apr & $\mathrm{W}$ & 10.5 & 64.9 & 90 & 66 & 53 & 44 & 17 & 3.8 & 2.9 \\
\hline May & SW & 8.0 & 52.8 & 96 & 74 & 63 & 52 & 26 & 4.1 & 3.9 \\
\hline Jun & SW & 7.2 & 66.8 & 103 & 82 & 71 & 61 & 34 & 4.4 & 4.7 \\
\hline Jul & SW & 6.4 & 75.0 & 106 & 85 & 74 & 65 & 46 & 3.9 & 3.7 \\
\hline Aug & $\mathrm{NE}$ & 5.1 & 62.9 & 102 & 84 & 74 & 64 & 41 & 3.3 & 5.3 \\
\hline Sep & $\mathrm{S}$ & 6.6 & 55.0 & 102 & 78 & 66 & 56 & 31 & 2.6 & 4.8 \\
\hline Oct & SSW & 7.8 & 42.0 & 90 & 66 & 54 & 45 & 20 & 2.4 & 3.8 \\
\hline Nov & $\mathrm{S}$ & 7.6 & 49.9 & 80 & 54 & 45 & 36 & 1 & 3.1 & 3.3 \\
\hline Dec & $\mathrm{W}$ & 10.3 & 55.9 & 73 & 41 & 33 & 26 & -17 & 2.9 & 2.3 \\
\hline Ann & $\mathrm{W}$ & 9.5 & 75.0 & 106 & 64 & 53 & 44 & -20 & 38.8 & 5.3 \\
\hline
\end{tabular}




\section{CHAPTER 18}

\section{YUMA PROVING GROUND}

\subsection{Introduction}

Arizona's Yuma Proving Ground (YPG) is provided with daily and specialized forecasts in support of range operations during normal duty hours to include severe weather warnings. Radiosondes launched every other hour from four fixed sites and from two mobile sites are on demand. This service is normally provided Monday through Saturday during working hours; however, frequent late night or early morning mission support is provided.

The meteorology section at YPG supports twenty fixed and eight portable surface stations which measure temperature, humidity, wind speeds and direction, and solar radiation. Soil temperature (skin surface temperature), wet bulb globe temperature, visibility distances, precipitation, and pressure measurements are other needs provided for daily and mission support. One additional fixed site records soil moisture and soil temperature at five depths. The area also has four direct-fire ranges that require head and cross wind information provided from 5-10 towers ranging from $0-5 \mathrm{~km}$ from the gun. Specialized data collection of scintillation, relative transmissivity, ultraviolet solar radiation, and ozone concentration can be provided as required.

\subsection{Weather Instrumentation}

a. Weather Radar Type: Doppler.

(1) Specifics: A NEXRAD Doppler radar that is located near Somerton, Arizona, operated by the National Weather Service. It is used for daily forecasts as well as monitoring storm locations and intensity for mission support.

(2) Purpose: daily range operations, and missions.

(3) Uses: Precipitation location and intensity, lightning monitoring, and rainfall and flash flood warning.

b. Satellite: GOES-11 and GOES-12.

c. Upper Air: radiosondes.

Specifics: 4,000+ upper air flights for direct mission support per year.

d. Surface:

(1) Rain gauge: WEATHERtronics 6010 tipping buckets.

(2) Anemometer: RM Young 5103 wind monitors; RM Young 27005 UVW sensors; RM Young 85000 sonic anemometers.

(3) Scintillation: Long-Range Optical Anemometers (LOA).

(4) Manual surface observations: NOVALynx standard rain gauge.

(5) Other: Campbell Scientific CS115 barometers, Campbell Scientific HMP45-C thermohygrometers, Campbell Scientific 108 soil temperature probes, Star 3020 Pyranometers, LOA, Small Portable Transmissometer (SPOT), Campbell Scientific CR300 data loggers, ultraviolet radiation sensors, ozone meter. 
e. Lightning Detection: stand-alone sensor.

(1) National lightning data from Weather Bug.

(2) Specifics: data used for forecasting, issuing warnings, and general mission support.

f. Specialized NWP models: Local model called 4DWx developed and maintained in cooperation with NCAR.

TABLE 18-1. YUMA PROVING GROUND CLIMATOLOGY

\begin{tabular}{|c|c|c|c|c|c|c|c|c|c|c|}
\hline \multirow{3}{*}{ Month } & \multirow{2}{*}{\multicolumn{3}{|c|}{$\begin{array}{c}\text { Winds (knots) } \\
\text { Prevailing } \\
\end{array}$}} & \multicolumn{5}{|c|}{ Temperature $\left({ }^{\circ} \mathbf{F}\right)$} & \multicolumn{2}{|c|}{ Precip (inches) } \\
\hline & & & & \multirow{2}{*}{$\begin{array}{l}\text { Abs } \\
\text { Max } \\
\end{array}$} & \multirow{2}{*}{$\begin{array}{l}\text { Avg } \\
\text { Max } \\
\end{array}$} & \multirow{2}{*}{ Avg } & \multirow{2}{*}{$\begin{array}{l}\text { Avg } \\
\text { Min } \\
\end{array}$} & \multirow{2}{*}{$\begin{array}{l}\text { Abs } \\
\text { Min }\end{array}$} & \multirow{2}{*}{$\begin{array}{c}\text { Mon } \\
\text { Avg } \\
\end{array}$} & \multirow{2}{*}{$\begin{array}{l}24 \mathrm{hr} \\
\text { Max }\end{array}$} \\
\hline & Dir & Spd & Peak & & & & & & & \\
\hline Jan & $\mathrm{N}$ & 8 & 45.1 & 88 & 69 & 57 & 44 & 24 & 0.4 & 1.2 \\
\hline Feb & $\mathrm{N}$ & 8 & 44.1 & 97 & 74 & 61 & 47 & 28 & 0.2 & 0.6 \\
\hline Mar & $\mathrm{W}$ & 8 & 47.0 & 100 & 79 & 65 & 51 & 32 & 0.2 & 0.7 \\
\hline Apr & $\mathrm{W}$ & 8 & 52.1 & 111 & 87 & 72 & 57 & 34 & 0.1 & 1.1 \\
\hline May & $\mathrm{W}$ & 8 & 40.0 & 117 & 94 & 79 & 64 & 46 & 0.1 & 0.4 \\
\hline Jun & $\mathrm{S}$ & 7 & 32.1 & 122 & 103 & 88 & 72 & 54 & 0.0 & 0.2 \\
\hline Jul & $\mathrm{S}$ & 8 & 54.0 & 124 & 107 & 94 & 80 & 63 & 0.2 & 2.6 \\
\hline Aug & $\mathrm{S}$ & 8 & 45.1 & 120 & 106 & 93 & 80 & 63 & 0.5 & 3.4 \\
\hline Sep & $\mathrm{S}$ & 7 & 59.1 & 123 & 102 & 88 & 74 & 53 & 0.3 & 2.4 \\
\hline Oct & $\mathrm{N}$ & 7 & 49.0 & 112 & 91 & 77 & 62 & 35 & 0.3 & 2.2 \\
\hline Nov & $\mathrm{N}$ & 8 & 40.0 & 98 & 78 & 64 & 51 & 30 & 0.2 & 1.4 \\
\hline Dec & $\mathrm{N}$ & 8 & 34.0 & 86 & 69 & 57 & 44 & 25 & 0.4 & 1.8 \\
\hline Ann & var & 8 & 59.1 & & & & & & & 3.4 \\
\hline
\end{tabular}

